\title{
The risk of cross-border pollution and the influence of regional climate on the rainwater chemistry in the Southern Carpathians, Romania
}

\author{
Ágnes Keresztesi ${ }^{1,2,3} \cdot$ Ion-Andrei Nita ${ }^{4,5} \cdot$ Marius-Victor Birsan ${ }^{5} \cdot$ Zsolt Bodor $^{2} \cdot$ Róbert Szép $^{1,2,3}$ (D)
}

Received: 1 June 2019 / Accepted: 19 December 2019 / Published online: 8 January 2020

(C) The Author(s) 2020

\begin{abstract}
The aim of this study is the assessment of rainwater composition, regarding the various sources of major ions and heavy metals, taking into account the characteristic atmospheric circulations and the main air mass transport routes. Rainwater samples were analyzed for $\mathrm{pH}$, electrical conductivity, major ions, and heavy metals. At all sampling sites, the most abundant anions were $\mathrm{SO}_{4}{ }^{2^{-}}$ and $\mathrm{Cl}^{-}$, while the dominant cations were $\mathrm{Ca}^{2+}$ and $\mathrm{Mg}^{2+}$. Regarding heavy metals, the dominance of $\mathrm{Pb}$ and $\mathrm{Cd}$ was found. The contribution of soil dust from the mining activities and the dissolution of $\mathrm{CaCO}_{3}, \mathrm{MgCO}_{3}$, and $\mathrm{CaSO}_{4} \cdot 2 \mathrm{H}_{2} \mathrm{O}$ in the rainwater explains the high concentrations of $\mathrm{Ca}^{2+}, \mathrm{Mg}^{2+}$, and $\mathrm{SO}_{4}{ }^{2-}$. The overall precipitation contamination with heavy metals at the three sampling sites was assessed by the degree of contamination, showing that $\mathrm{Pb}$ and $\mathrm{Cd}$ presents the highest risks of all heavy metals. The values of toxicity potential suggested an elevated risk for human health in case of rainwater ingestion, especially in rural areas. Spearman correlation and PCA indicated that the chemical characteristic of the rainwater is primarily controlled by sources such as agricultural activities, mixed and crustal sources, traffic, and other anthropogenic, industrial influences, mining activities, smelting operations, coal combustion, and metal production.
\end{abstract}

Keywords Rainwater chemistry $\cdot$ Ecological risk $\cdot$ Heavy metals $\cdot$ Wet deposition $\cdot$ Long-range transport $\cdot$ Source analysis

\section{Introduction}

Atmospheric precipitation is one of the most debated subjects worldwide, because of awareness of the impact of acid rain on the environment and human health, but it also provides useful information about the composition of the atmosphere and the

Responsible editor: Severine Le Faucheur

Róbert Szép

szeprobert@uni.sapientia.ro

1 Faculty of Natural Sciences, Doctoral School of Chemistry, University of Pécs, Ifjúság 6, Pécs 7624, Hungary

2 Department of Bioengineering, Sapientia Hungarian University of Transylvania, Piaţa Libertății 1, 530104 Miercurea Ciuc, Romania

3 Institute for Research and Development for Hunting and Mountain Resources, Progresului 35B, 530240 Miercurea Ciuc, Romania

4 Alexandru Ioan Cuza University, Bulevardul Carol I 11, 700506 Iaşi, Romania

5 National Meteorology Administration, Soseaua București-Ploiești 97, District 1, 013686 Bucharest, Romania importance of different sources of gaseous and particulate pollutants. Characteristics of rainwater chemistry in urban areas can be attributed to local emission sources, while in remote and rural areas, it can be referred to the impact of natural and anthropogenic sources (Tiwari et al. 2008; Keresztesi et al. 2019). Type and distribution of aerosol sources, transport, and scavenging processes of chemical species are just a few of the multiple factors that can influence the concentrations of chemical species in rainwater (Celle-Jeanton et al. 2009). Rainwater chemistry is also characterized by the complex interactions between the dynamics of clouds and microphysical processes, as well as different atmospheric chemical reactions that occur in-cloud and below-cloud (Herrera et al. 2009). The chemical composition of precipitation can also be affected by rainfall rate and amount, cloud base height, and the air mass back trajectories (Báez et al. 1997), varying from site to site and region to region $(\mathrm{Pu}$ et al. 2017), indicating the local influences and characteristics of atmospheric pollutants. Rainwater composition reflects the quality of the atmosphere during the occurrence of rainfall (Mahato et al. 2016). 
The study of heavy metals concentration in rainwater has increased in the last decades due to their significant effects on the environment and human health (Báez et al. 2007). Heavy metals, such as $\mathrm{Cd}$ and $\mathrm{Pb}$, are toxic and highly bioavailable, hence they can be easily accumulated by the biosphere and living organisms (Galloway et al. 1982). Anthropogenic activities, including mining, industry, coal burning, and automobile exhaust, are known to be the most significant sources of heavy metals concentration in precipitation. Trace metals are also deposited by precipitation to the surface of waters and soils and may have harmful effects on the ecosystem. Pollutants from the atmosphere are mainly deposited by the in-cloud scavenging (rainout) and below-cloud scavenging (washout) processes. According to Valenta et al. (1986) over $80 \%$ of wet deposited heavy metals are dissolved in rainwater, favoring the uptake of these pollutants by vegetation. Another factor influencing the rainwater chemistry and its composition are atmospheric circulations, by acting on radiation, temperature, and precipitation conditions (Falarz 2007). Foehn winds and the Foehn effect present in the studied area are of great importance, since the air masses are subjected to an additional warming and dehumidification, impacting the sea salt content in the rainwater. Emissions of air pollutants, especially the increased sulfur and nitrate concentrations in urban areas, are due to growth in population, industrialization, mining, energy consumption, transport, agricultural production, etc. Mining activities affect relatively small areas but can have a large local impact on the environment (Salomons 1995). Release of metals from mining sites occurs primarily through acid mine drainage and erosion of waste dumps and tailings deposits (Salomons 1995).

The role of local contribution versus long-range transport supply in the rainwater chemistry was investigated by the collection of rainwater samples during January 2014 and December 2017 at three sampling sites in the Southern and Western Carpathians. The studied area is one of the largest mining regions from Europe, known for its un-rehabilitated tailings ponds, tailings dams, and slag deposits, where thousands of tons of hazardous waste were gathered during mining operations. Surface mining activities are direct sources of air pollution and polluted atmospheric precipitation. While the European Union is trying to stop pollution and prevent the effects of global warming, the Romanian state is still confronting with serious problems regarding the closure and greening of the tailing ponds. One of the worst cases in the west of the country is the Bossneag decantation pond, Moldova Nouă, Caraş-Severin County. A mining operation started here 40 years ago, exploiting complex minerals, especially iron and copper (pyrite, chalcopyrite, etc.), while the banks of the Danube were nothing but settling ponds where thousands of tons of hazardous waste were gathered. Zinc, nitrates, and other metals have penetrated the soil and the water of the river. In the early 2000 s, exploitation began to decline, and the exploitation was quickly shut down, leaving behind millions of tons of ore residues, which were used in the production process. The studied area represents a major pollution source, with thin particles of hazardous dust being carried in the atmosphere by the wind and transported to the neighboring shore in Serbia (Burlacu et al. 2017).

The main aim of this paper is the analysis of the effects of major ions and trace elements deriving from the tailing ponds, which have a high mineral charge, on the rainwater chemistry. Also, the study investigates the atmospheric circulation impact and the Foehn effect on the rainwater chemistry, taking into account the main air mass transport routes in order to explain the origin of the pollutants and relationship between major ions, providing a preliminary understanding of the influencing factors regarding the lack of sea salt contribution, and the presence of anthropogenic and crustal sources. The relationship between precipitation chemistry and pollutants deriving from anthropogenic activities was further examined using different atmospheric modeling techniques, in order to show the contribution of regional and continental air masses to the precipitation chemistry in one of the most polluted regions from Europe.

\section{Materials and methods}

\section{Sampling sites and analysis}

The studied area is situated in the Southern and Western Carpathians, South-West Romania, on the border with Serbia. This region is known for its great relief diversity, where all three classical forms of relief are present, but the mountains are predominant, representing $65.4 \%$ of the total surface of the studied region. The mountainous region has different characters due to its diverse geological and lithological structure, being represented by Banat Mountains, the western extremity of the Southern Carpathians ( arcu, Godeanu, Cernei, and Mehedinți mountains) and the most southern part of the Western Carpathians (the southern peaks of Poiana Ruscă Mountains). The mountainous relief rises in altitude from west to east, culminating in the Godeanu Mountains, with their heights of 1600-2200 m, rising far above the southern part of the Poiana Ruscă Mountains (1355 m).

Due to its geographical position, not far from the Adriatic Sea and in the shelter of the Southern and Western Carpathians, the studied area's climate is temperate continental, with sub-Mediterranean influences. This climate type is characterized by Atlantic air masses circulation and the invasion of Mediterranean air masses, giving a moderate character to the thermal regime, with frequent warm periods in the winter, early springtime, and relatively large amounts of rainfall. Precipitation amount increases from $700 \mathrm{~mm}$ in the low areas to $1400 \mathrm{~mm}$ in the arcu and Godeanu Mountains. The predominance throughout the year of the advent of wet air masses 
in the west and southwest, as well as the more intense frontal activity, gives the main feature of the climate.

In order to analyze chemical composition of rainwater and the effects of the tailing ponds on the concentration of major ions and heavy metals, a total of 81 rainwater samples were collected at Reşiţa, 97 at Moldova Nouă and also 97 samples at Băile Herculane, from January 1, 2014 to December 31, 2017. The selected locations for rainwater sampling are significant in terms of mining and industry: Municipality of Reşiţa (RS) $\left(45^{\circ}\right.$ $\left.30^{\prime} \mathrm{N}, 21^{\circ} 88^{\prime} \mathrm{E}\right)$ where steel and machinery industry is well developed, Moldova Nouă (MN) $\left(44^{\circ} 73^{\prime} \mathrm{N}, 21^{\circ} 66^{\prime} \mathrm{E}\right)$ and Băile Herculane (BH) $\left(44^{\circ} 87^{\prime} \mathrm{N}, 22^{\circ} 41^{\prime} \mathrm{E}\right)$. The geographical distribution of the sampling sites is shown in Fig. 1.

Rainwater samplers were placed about $1.5-2 \mathrm{~m}$ above ground, from the onset until the end of the precipitation event. In order to prevent/minimize any possible contamination, the samplers were thoroughly washed and rinsed before and after each collecting operation. After precipitation samples were collected, a small amount of thymol was added to all the samples to avoid biological degradation, and then samples were kept at $4{ }^{\circ} \mathrm{C}$ until ion composition analysis $\left(\mathrm{SO}_{4}{ }^{2-}\right.$, $\mathrm{NO}_{3}^{-}, \mathrm{NO}_{2}^{-}, \mathrm{Cl}^{-}, \mathrm{NH}_{4}^{+}, \mathrm{Ca}^{2+}, \mathrm{Na}^{+}, \mathrm{K}^{+}, \mathrm{Mg}^{2+}$ ). After each sampling, $\mathrm{pH}$ and conductivity were immediately measured, using digital $\mathrm{pH}$ meters standardized with 4.0 and $9.2 \mathrm{pH}$ buffer solutions and conductivity meters. The anions $\left(\mathrm{SO}_{4}{ }^{2-}\right.$, $\mathrm{NO}_{3}{ }^{-}, \mathrm{NO}_{2}{ }^{-}$) were analyzed by ion chromatograph (Dionex 2000i/SP) using a $\mathrm{CO}_{3}{ }^{2-} / \mathrm{HCO}_{3}{ }^{-}$buffer as eluent $(1.7 \mathrm{mM}$ $\mathrm{Na}_{2} \mathrm{CO}_{3} / 1.8 \mathrm{mM} \mathrm{NaHCO}$ ), used in isocratic analysis, and $25 \mathrm{mM} \mathrm{H}_{2} \mathrm{SO}_{4}$ as regenerant. A total of $100 \mathrm{ppm}$ stock solutions of sodium salts of each of the ions were prepared. The concentrations were calculated based on the peak area of the above-mentioned standards. After every five samples, peak response was checked, by running standards I triplicates.
Recalibration was necessary if the deviation was more than $2 \%$. Cations $\left(\mathrm{Na}^{+}, \mathrm{Ca}^{2+}, \mathrm{Mg}^{2+}\right.$, and $\left.\mathrm{K}^{+}\right)$and heavy metals $(\mathrm{Pb}$, $\mathrm{Ni}, \mathrm{As}, \mathrm{Cd}$ ) were measured by inductively coupled plasmaatomic emission spectroscopy (ICP-AES, iCAP 6300 Duo View ICP-AES Spectrometer) after acidification to $\mathrm{pH}<2$ with $\mathrm{HNO}_{3}$. The $\mathrm{Cl}^{-}$and $\mathrm{NH}_{4}{ }^{+}$were measured by U-VIS spectrometer method (Nicolet Evolution 100, 463 and $440 \mathrm{~nm}$ ) (Nollet 2007; Szép et al. 2017).

\section{Data quality}

To verify the completeness and correctness of precipitation data, ion balance technique was used. The data is generally considered acceptable, if the equivalent ratio of the sum of anions and sum of cations ( $\Sigma$ anions $/ \Sigma$ cations) is around one, with ion imbalances that does not exceed $\pm 25 \%$ (Keene et al. 1986; Wu et al. 2016). The ionic balance of total anions and cations for the precipitation samples was as follows: $0.75 \pm 0.58$ at $\mathrm{RS}, 0.77 \pm 0.49$ at $\mathrm{MN}$ and $0.77 \pm 0.58$ at BH. Eventual anion deficiencies observed in the ionic balances of the collected samples indicate the presence $\mathrm{HCO}_{3}{ }^{-}$, which can be estimated using the empirical method of Granat (1972), to lower the deviations from unity:

$$
\left[\mathrm{HCO}_{3}^{-}\right]=10^{-11.24+\mathrm{pH}}(\mathrm{eq} / \mathrm{l})
$$

After taking under consideration the calculated $\mathrm{HCO}_{3}{ }^{-}$ concentrations, the ionic balance indicated significantly higher values at all 3 sampling sites being $0.82 \pm 0.61$ at RS, $0.90 \pm 0.61$ at $\mathrm{MN}$, and $0.94 \pm 0.70$ at $\mathrm{BH}$, respectively. Further anion deviation in ion balance might be due to the presence of organic compounds such as acetate, formate,

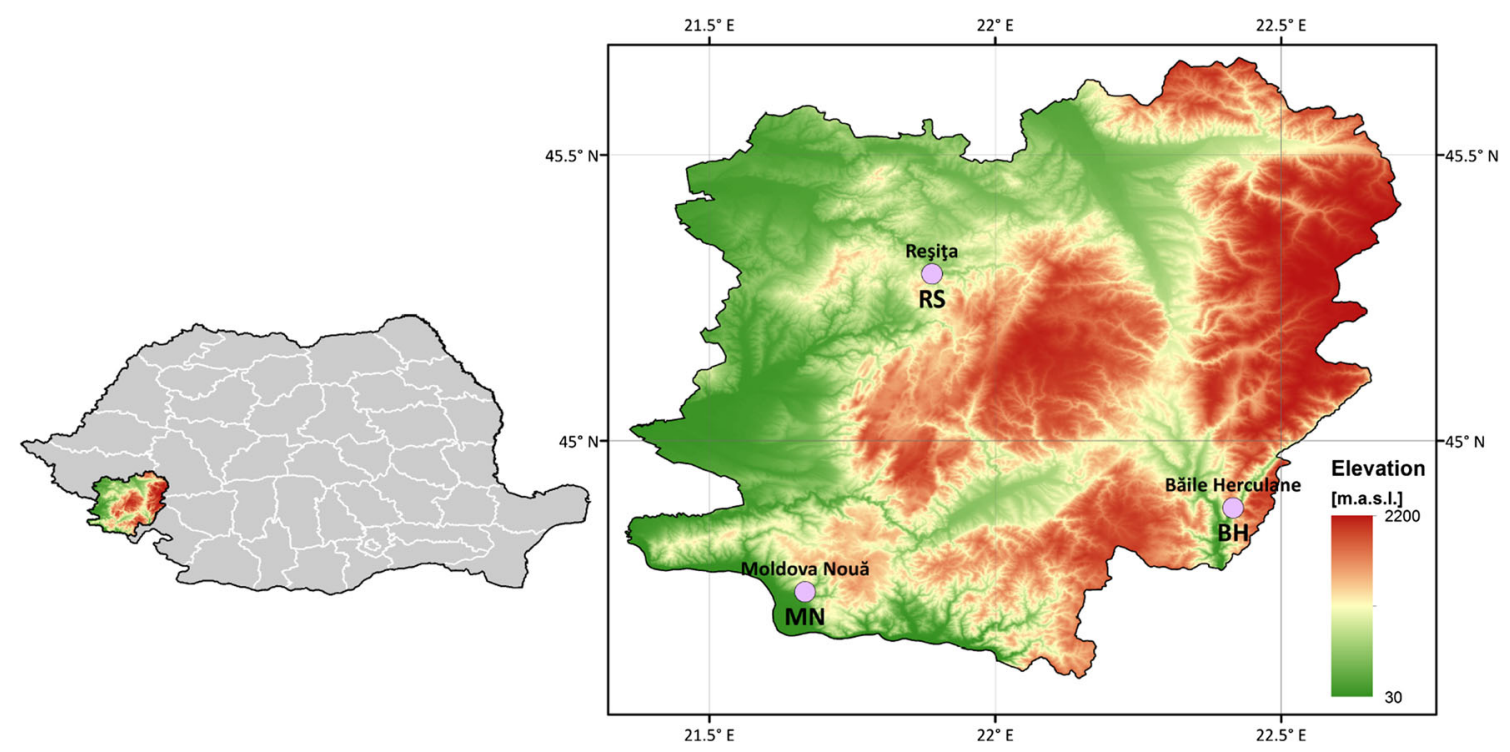

Fig. 1 Sampling sites (RS, MN, BH), Southern and Western Carpathians, Romania 
and oxalate, emitted in the atmosphere by the biomass (Honório et al. 2010), that were not measured due to analytical limitations.

\section{Classification of atmospheric circulation types}

Atmospheric circulations are important in the study of precipitation in certain areas as shown previously (Esteban et al. 2005; Haylock et al. 2008; Brisson et al. 2011; Fleig et al. 2015). For our purpose, we used a daily classification of circulation types (CT) in order to investigate the links between certain synoptic patterns and precipitation in southeastern Europe. In this manner, we used the mean sea-level pressure (MSLP) retrieved from ERA-Interim (Dee et al. 2011) as input and cost733class software (Philipp et al. 2016) in order to construct an objective and automatic classification of weather types. The classification chosen here is called GrossWetterTypen (GWT) which uses predefined thresholds in order to assign each day to a specific circulation type (Beck et al. 2007). A total of 27 weather types over the period 1979 2018 were obtained. We selected six weather types resembling to cyclonic formations upon the eastern Mediterranean basin that can lead to precipitation occurrence in the study area (Fig. 2). For each CT, we constructed the multi-annual mean of precipitation sums in order to visualize the distribution of rainfall upon southeastern Europe.

Daily gridded precipitation data from E-OBS (v20e) is used here at a spatial resolution of 0.1 degrees. This data is using the mean from 100-member ensemble in order to remove the uncertainties resulted from multiple interpolation methods (Cornes et al. 2018).

\section{Multivariate statistical analysis}

Principal component analysis (PCA) is a multivariate statistical technique that can be applied in order to identify possible associations among the variables in a dataset, being frequently used to distinguish the relationships and the correspondence between different ionic species and elements in precipitation (Plaisance et al. 1996; Lara et al. 2001; Varmuza and
Filzmoser 2010). A varimax rotation was applied to maximize the variance and to obtain a pattern of loadings for each factor (Cheng et al. 2011). The datasets were processed using the IBM SPSS version 23 statistical program.

\section{Cluster analysis}

Meteorological classification refers to the identification of distinct patterns that influence climate-/weather-related variables (Riccio et al. 2007; Izquierdo et al. 2012). In order to classify the air mass origin arriving at a site, cluster analysis can be used.

However, cluster analysis does not provide further information on the geographical location of potential source regions (Izquierdo et al. 2012). In the present study, air mass movement is analyzed at the studied locations. During the simulations, the Hybrid Single Particle Lagrangian Integrated Trajectory Model (HYSPLIT) (Draxler and Rolph 2013) was used to quantitatively analyze the distribution of aerosols based on $1^{\circ} \times 1^{\circ}$ meteorological data (GDAS- Global Data Assimilation System) from NCEP. In order to find the dominant trajectories, cluster analysis was used (Anil et al. 2017).

\section{Results and discussions}

\section{Major ion and heavy metal concentrations of rainwater}

Statistical results of all analyzed ion and trace element concentrations in rainwater samples collected at three different sampling sites in the Southern Carpathians are given in Table 1, along with $\mathrm{pH}$, volume-weighted mean (VWM), standard deviation (st. dev.), and standard error (st. error). Relatively high standard deviations of major ion concentrations at all sampling sites indicates great differences in the cation and anion concentrations over the precipitation events (Wu et al. 2012), while the lower VWM concentrations of ions than the arithmetic means suggest that lower rainfalls are usually accompanied by higher concentrations (Lü et al. 2017). This inverse relationship is probably due to the below-cloud
Fig. 2 Distribution of rainwater $\mathrm{pH}$ at Resita (RS), Moldova Noua $(\mathrm{MN})$, and Baile Herculane (BH)

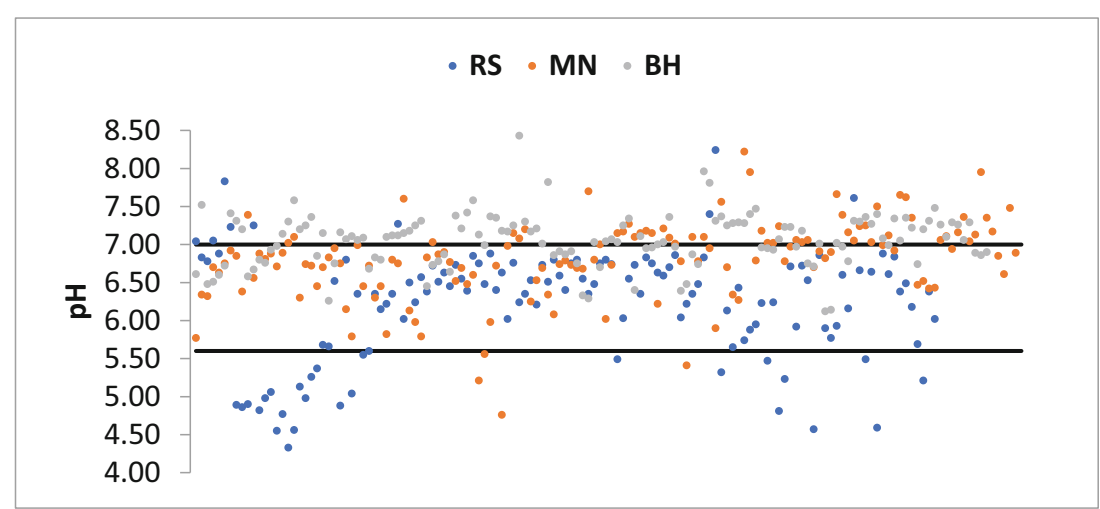


Table 1 Volume-weighted mean (VWM) concentration of major ion (in $\mu$ eq $1^{-1}$ ), heavy metals (in $\mu \mathrm{gl}^{-1}$ ), and $\mathrm{pH}$ along with statistical results in rainwater samples

\begin{tabular}{|c|c|c|c|c|c|c|c|c|c|c|c|c|c|c|c|c|}
\hline Component & $\mathrm{pH}$ & $\mathrm{Na}^{+}$ & $\mathrm{K}^{+}$ & $\mathrm{Ca}^{2+}$ & $\mathrm{Mg}^{2+}$ & $\mathrm{SO}_{4}^{2-}$ & $\mathrm{Cl}^{-}$ & $\mathrm{NO}_{2}^{-}$ & $\mathrm{NO}_{3}^{-}$ & $\mathrm{NH}_{4}^{+}$ & $\mathrm{HCO}_{3}^{-}$ & $\mathrm{H}^{+}$ & $\mathrm{Pb}$ & $\mathrm{Ni}$ & As & $\mathrm{Cd}$ \\
\hline \multicolumn{17}{|l|}{ RS } \\
\hline VWM & 6.03 & 37.38 & 15.13 & 132.28 & 68.82 & 49.72 & 132.90 & 2.46 & 18.80 & 94.94 & 24.35 & 4.55 & 1.22 & 0.23 & 0.29 & 0.89 \\
\hline Average & 6.18 & 38.21 & 15.77 & 158.48 & 78.10 & 61.87 & 129.39 & 2.60 & 20.65 & 99.23 & 31.39 & 3.17 & 1.28 & 0.20 & 0.34 & 0.74 \\
\hline St. dev. & 0.75 & 40.94 & 22.96 & 135.00 & 73.50 & 48.61 & 55.20 & 3.30 & 18.87 & 60.19 & 98.63 & 7.02 & 0.77 & 0.24 & 0.21 & 0.60 \\
\hline St. error & 0.07 & 3.69 & 2.07 & 12.17 & 6.63 & 4.38 & 4.98 & 0.30 & 1.70 & 5.43 & 8.89 & 0.63 & 0.07 & 0.02 & 0.02 & 0.05 \\
\hline Min. & 4.33 & 3.44 & 0.97 & 5.29 & 1.65 & 10.41 & 20.03 & 0.11 & 0.18 & 0.33 & 0.12 & 0.01 & 0.17 & 0.02 & 0.06 & 0.16 \\
\hline Max. & 8.24 & 247.94 & 129.42 & 799.94 & 473.98 & 291.48 & 400.53 & 22.21 & 116.06 & 262.22 & 1000.00 & 46.77 & 2.84 & 0.83 & 0.61 & 2.76 \\
\hline \multicolumn{17}{|l|}{$\mathrm{MN}$} \\
\hline VWM & 6.78 & 7.38 & 17.50 & 356.73 & 189.46 & 200.35 & 159.04 & 5.28 & 27.81 & 123.78 & 57.88 & 0.29 & 2.77 & 1.87 & 0.25 & 8.84 \\
\hline Average & 6.81 & 35.87 & 21.20 & 367.31 & 219.42 & 240.91 & 160.72 & 5.39 & 27.73 & 130.00 & 68.16 & 0.45 & 2.84 & 1.10 & 0.26 & 8.68 \\
\hline St. dev. & 0.52 & 54.76 & 21.13 & 252.54 & 234.56 & 155.92 & 74.77 & 6.29 & 32.00 & 94.46 & 106.50 & 1.58 & 1.80 & 2.64 & 0.18 & 3.03 \\
\hline St. error & 0.04 & 4.63 & 1.79 & 21.34 & 19.82 & 13.18 & 6.32 & 0.53 & 2.70 & 7.98 & 9.00 & 0.13 & 0.16 & 0.24 & 0.02 & 0.27 \\
\hline Min. & 4.76 & 3.52 & 1.79 & 28.44 & 3.79 & 20.82 & 20.03 & 0.07 & 0.35 & 16.63 & 0.33 & 0.01 & 0.74 & 0.05 & 0.00 & 1.99 \\
\hline Max. & 8.22 & 430.54 & 135.40 & 1574.43 & 1026.95 & 874.43 & 600.80 & 36.10 & 212.89 & 398.04 & 954.99 & 17.38 & 7.29 & 8.91 & 0.54 & 15.32 \\
\hline \multicolumn{17}{|l|}{$\mathrm{BH}$} \\
\hline VWM & 7.02 & 14.17 & 17.46 & 382.16 & 201.86 & 204.87 & 162.65 & 7.25 & 12.80 & 93.13 & 86.44 & 0.13 & 4.15 & 1.40 & 0.38 & 7.73 \\
\hline Average & 7.06 & 50.88 & 18.39 & 422.53 & 218.05 & 226.33 & 162.46 & 6.25 & 12.13 & 86.95 & 93.67 & 0.12 & 3.08 & 1.17 & 0.35 & 7.74 \\
\hline St. dev. & 0.35 & 163.42 & 13.52 & 382.38 & 192.82 & 115.99 & 91.33 & 6.64 & 15.15 & 382.52 & 142.09 & 0.12 & 2.29 & 2.21 & 0.20 & 1.30 \\
\hline St. error & 0.03 & 13.96 & 1.16 & 32.67 & 16.47 & 9.91 & 7.80 & 0.57 & 1.29 & 6.45 & 12.14 & 0.01 & 0.21 & 0.20 & 0.02 & 0.12 \\
\hline Min. & 6.12 & 5.65 & 2.81 & 34.93 & 4.94 & 20.82 & 20.03 & 0.09 & 0.35 & 3.88 & 7.59 & 0.00 & 0.62 & 0.15 & 0.09 & 5.50 \\
\hline Max. & 8.43 & 1360.17 & 72.89 & 2319.98 & 789.96 & 687.05 & 520.69 & 30.39 & 127.89 & 382.52 & 1548.82 & 0.76 & 8.90 & 7.46 & 0.56 & 10.35 \\
\hline
\end{tabular}

removal process during precipitation events (De Souza et al. 2006; Wu et al. 2016).

Major ion concentration in the case of RS followed the descending sequence of $\mathrm{Cl}^{-}>\mathrm{Ca}^{2+}>\mathrm{NH}_{4}^{+}>\mathrm{Mg}^{2+}>\mathrm{SO}_{4}^{2}$ ${ }^{-}>\mathrm{Na}^{+}>\mathrm{HCO}_{3}{ }^{-}>\mathrm{NO}_{3}{ }^{-}>\mathrm{K}^{+}>\mathrm{H}^{+}>\mathrm{NO}_{2}{ }^{-}$. The predominant cations were $\mathrm{Ca}^{2+}, \mathrm{NH}_{4}^{+}$, and $\mathrm{Mg}^{2+}$ accounting for $83.84 \%$ of the total sum of cations, while $\mathrm{Cl}^{-}$was the predominant anion and contributed $58.23 \%$ of the total mass of anions. Major ion concentration in rainwater collected at $\mathrm{MN}$ followed the descending sequence $\mathrm{Ca}^{2+}>\mathrm{SO}_{4}{ }^{2-}>\mathrm{Mg}^{2+}>$ $\mathrm{Cl}^{-}>\mathrm{NH}_{4}{ }^{+}>\mathrm{HCO}_{3}{ }^{-}>\mathrm{NO}_{3}{ }^{-}>\mathrm{K}^{+}>\mathrm{Na}^{+}>\mathrm{NO}_{2}{ }^{-}>\mathrm{H}^{+}, \mathrm{Ca}^{2+}$ being the predominant cation accounting for $51.32 \%$ of the total mass of the cations, and $\mathrm{SO}_{4}{ }^{2-}$ being the most abundant anion, representing $44.49 \%$ of the total anionic mass. Almost the same can be said about the precipitation samples collected at $\mathrm{BH}$, with the major ion concentration following the descending order: $\mathrm{Ca}^{2+}>\mathrm{SO}_{4}{ }^{2-}>\mathrm{Mg}^{2+}>\mathrm{Cl}^{-}>\mathrm{NH}_{4}{ }^{+}>$ $\mathrm{HCO}_{3}{ }^{-}>\mathrm{K}^{+}>\mathrm{Na}^{+}>\mathrm{NO}_{3}{ }^{-}>\mathrm{NO}_{2}{ }^{-}>\mathrm{H}^{+}$. The dominant cations were $\mathrm{Ca}^{2+}$ and $\mathrm{Mg}^{2+}$ accounting for $53.91 \%$ and $28.47 \%$ of the total cationic mass, respectively. $\mathrm{SO}_{4}{ }^{2-}$ is the predominant anion, representing $43.22 \%$ of the total sum of anions. High concentrations of $\mathrm{Ca}^{2+}$ and $\mathrm{Mg}^{2+}$ collected at the sampling sites are due to the large contribution of soil dust from the un-rehabilitated tailing dams, from the dolomite limestones.
The dissolution of calcite $\left(\mathrm{CaCO}_{3}\right)$, dolomite $\left(\mathrm{MgCO}_{3}\right)$, and gypsum $\left(\mathrm{CaSO}_{4} \cdot 2 \mathrm{H}_{2} \mathrm{O}\right)$ in the rainwater explains the high concentrations of $\mathrm{Ca}^{2+}, \mathrm{Mg}^{2+}$, and $\mathrm{SO}_{4}{ }^{2-}$ in the studied areas.

Among heavy metal content in rainwater, at $\mathrm{RS}, \mathrm{Pb}$ presented the highest concentration, followed by $\mathrm{Cd}$, while at $\mathrm{MN}$ and $\mathrm{BH}$, $\mathrm{Cd}$ was the most abundant element, followed by $\mathrm{Pb}$, the latter being 3 , respectively 2 times lower than the concentrations measured for $\mathrm{Cd}$. Ni and As were the least concentrated, having similar concentrations at $\mathrm{RS}$, while at $\mathrm{MN}$ and $\mathrm{BH} \mathrm{Ni}$ was 7 and 4 times higher than As, respectively.

\section{Variation of $\mathrm{pH}$ and acid neutralization}

Naturally existing carbon dioxide can dissolve into the clouds and cloud droplets, resulting in the water carbonic acid forms. (Wang and Han 2011). At normal concentrations and pressures of carbon dioxide in the atmosphere, the $\mathrm{pH}$ of rain and snow usually tends to be 5.6 (Likens et al. 1979; Wang and Han 2011). pH values lower than 5.6 indicate a significant impact of anthropogenic activities on rainwater quality, while samples having $\mathrm{pH}$ values above 6 and 6.5 are suggesting a major quantity of alkaline species in the atmosphere and rainwater of the studied area (Cao et al. 2009). The $\mathrm{pH}$ values of individual precipitation events between 2014 and 2017 varied from 4.33 to 8.43 for the entire studied region with an average 
of 6.70 . About $7.32 \%$ of the rainwater events had $\mathrm{pH}$ values less than $5.6,56.83 \%$ of the total samples had $\mathrm{pH}$ values between 5.6 and 7 , while $35.85 \%$ presented higher values than 7 , with $0.73 \%$ of the total samples ranging between 7 and 8.43. The distribution of rainwater $\mathrm{pH}$ is showed in Fig. 2. Individual $\mathrm{pH}$ values at the sampling sites were also analyzed (Table 1). The most acidic $\mathrm{pH}$ (values < 5.6) were found at $\mathrm{RS}$, representing $20.16 \%$ of the collected samples. In the case of $\mathrm{MN}, 2.80 \%$ of the total samples yielded $\mathrm{pH}$ values lower than 5.6, while at $\mathrm{BH}$ station, none of the rain events had $\mathrm{pH}$ values lower than 5.6 .

At RS and MN, the majority of the precipitation events had $\mathrm{pH}$ values between 5.6 and 7 , representing $72.87 \%$ and $59.44 \%$, respectively. $\mathrm{BH}$ had more alkaline $\mathrm{pH}$, with $60.87 \%$ of the total samples ranging between 7.00 and 8.43 . High $\mathrm{pH}$ values can result from the dissolution of windblown dust and can be derived from the weathering of carbonate with a high $\mathrm{CaCO}_{3}$ content (Wu et al. 2012).

The relatively high mean $\mathrm{pH}$ values measured in the studied region are mainly caused by the neutralization of acidity in rainwater, instead of lack of acidic compounds (Al-Momani et al. 2000).

This relationship is further confirmed by the neutralization percentage of alkaline species $\left(\mathrm{Ca}^{2+}, \mathrm{Mg}^{2+}\right.$, and $\left.\mathrm{NH}_{4}^{+}\right)$, which is estimated using the neutralization factors (NF) (Kulshrestha et al. 1995; Zhang et al. 2007):

$$
\mathrm{NF}_{\mathrm{xi}}=\frac{\left[X_{\mathrm{i}}\right]}{\left[\mathrm{SO}_{4}^{2-}\right]+\left[\mathrm{NO}_{3}^{-}\right]}
$$

where $\left[X_{\mathrm{i}}\right]$ is the concentration of the alkaline component $\left(\mathrm{Ca}^{2+}, \mathrm{NH}_{4}^{+}, \mathrm{Na}^{+}, \mathrm{K}^{+}, \mathrm{Mg}^{2+}\right)$ expressed in $\mu \mathrm{eq} / \mathrm{L}$.

As presented in Table $2, \mathrm{Ca}^{2+}$ is the most dominant neutralizing compound in precipitation at the three sampling sites, the average $\mathrm{NF}_{\mathrm{Ca}}$ values ranging between 1.56 at $\mathrm{MN}$ and 2.16 at CS for the 2014-2017 period. $\mathrm{Mg}^{2+}$ and $\mathrm{NH}_{4}{ }^{+}$were also significant neutralizing agents, their average NF values varied from 0.52 to 1.51. Neutralization effect of $\mathrm{K}^{+}$and $\mathrm{Na}^{+}$could be negligible, their NF values ranging between 0.09 and 0.61 .

According to Kaya and Tuncel (1997) and Wu et al. (2016), the acidification potential depends on the concentration of $\mathrm{H}_{2} \mathrm{SO}_{4}, \mathrm{HNO}_{3}$, and other organic acids in rainwater, while the neutralization potential on the competence of alkaline constituents to neutralize the acidic species (Rastogi and Sarin 2005). The acidic potential is the sum of the concentrations of $\mathrm{NO}_{3}{ }^{-}$and nss- $\mathrm{SO}_{4}{ }^{2-}$ and neutralization potential is the sum of the concentrations of $\mathrm{NH}_{4}{ }^{+}, \mathrm{nss}^{-\mathrm{Ca}^{2+}}$, nss- $\mathrm{Mg}^{2+}$, and nss$\mathrm{K}^{+}$(Kumar et al. 2002). Acidic potential can be used as a tracer of anthropogenic activities, while the neutralization potential as an indicator of air mass transport (Fujita et al. 2000). The AP/NP ratio was estimated for all three sampling locations and results are shown in Table 2. At all sampling sites, the average NP value is higher than the AP value, the ratio of $\mathrm{AP} / \mathrm{NP}$ varying from 0.31 at $\mathrm{RS}$ to 0.61 at $\mathrm{BH}$.

To further asses the relative contribution of different acidic or neutralizing compounds in rainwater, the $\mathrm{H}^{+} /\left(\mathrm{NO}_{3}{ }^{-}+\mathrm{SO}_{4}{ }^{2-}\right)$, $\left(\mathrm{NO}_{3}{ }^{-}+\mathrm{Cl}^{-}\right) /\left(\mathrm{SO}_{4}{ }^{2-}\right),\left(\mathrm{Ca}^{2+}+\mathrm{Mg}^{2+}+\mathrm{NH}_{4}{ }^{+}\right) /\left(\mathrm{NO}_{3}{ }^{-}+\mathrm{SO}_{4}{ }^{2-}\right)$, $\mathrm{SO}_{4}{ }^{2-} / \mathrm{NO}_{3}{ }^{-}, \mathrm{NH}_{4}{ }^{+} / \mathrm{NO}_{3}{ }^{-}$, and $\mathrm{NH}_{4}{ }^{+} / \mathrm{SO}_{4}{ }^{2-}$ ratios were calculated (Table 3) (Tiwari et al. 2016).

The ratio $\mathrm{H}^{+} /\left(\mathrm{NO}_{3}{ }^{-}+\mathrm{SO}_{4}{ }^{2-}\right)$, known as fractional acidity (FA), indicates whether or not the rainwaters acidity is neutralized (Balasubramanian et al. 2001; Anatolaki and Tsitouridou 2009). If the value of FA is close to one, the acidity in precipitation caused by strong acids $\left(\mathrm{H}_{2} \mathrm{SO}_{4} ; \mathrm{HNO}_{3}\right)$ is not neutralized at all. The average mean FA ratio varied from 0.001 to 0.08 , being far from unity, which indicates that on average, almost $99 \%$ of the inorganic acidity in precipitation is neutralized. The ratio of $\left(\mathrm{NO}_{3}{ }^{-}+\mathrm{Cl}^{-}\right) /\left(\mathrm{SO}_{4}{ }^{2-}\right)$ ranged between 0.98 $(\mathrm{BH})$ and $3.72(\mathrm{RS})$ in the studied area, indicating that where higher ratios were found ( $\mathrm{RS}, \mathrm{MN})$, nitric and hydrochloric acids have a larger contribution, while at $\mathrm{BH}$ where this ratio presented lower values, the influence of sulfuric acid is more significant (Singh et al. 2007). Another indicator for acidity is the ratio of $\left(\mathrm{SO}_{4}{ }^{2-}+\mathrm{NO}_{3}{ }^{-}\right) /\left(\mathrm{Ca}^{2+}+\mathrm{Mg}^{2+}\right)$, assuming that rainwaters acidity is primarily due to sulfate and nitrate (Jawad Al Obaidy and Joshi 2006). A ratio lower than one indicates the alkaline nature of precipitation, while a value greater than unity the presence of free anions (Jawad Al Obaidy and Joshi 2006). The values of the above-mentioned ratio presented values between $0.79(\mathrm{RS})$ and $1.00(\mathrm{BH})$, precipitation at RS and $\mathrm{MN}$, being more alkaline than at $\mathrm{BH}$, where the acidic components in rainwater are more significant. According to Tiwari et al. (2012), the equivalent ratio of $\left(\mathrm{Ca}^{2+}+\mathrm{Mg}^{2+}+\mathrm{NH}_{4}{ }^{+}\right) /$ $\left(\mathrm{NO}_{3}{ }^{-}+\mathrm{SO}_{4}{ }^{2-}\right)$ can be used as an indicator in the evaluation of anthropogenic activity contribution to the acidity of rainwater. This ratio at all sampling sites had high values, varying from $2.93(\mathrm{MN})$ to $4.68(\mathrm{RS})$, indicating that $\mathrm{Ca}^{2+}, \mathrm{Mg}^{2+}$, and $\mathrm{NH}_{4}{ }^{+}$ had a significant role in the neutralization process, in the form of $\mathrm{CaSO}_{4},\left(\mathrm{NH}_{4}\right)_{2} \mathrm{SO} 4$, and $\mathrm{MgSO}_{4}$. The ratio of $\mathrm{NH}_{4}{ }^{+} / \mathrm{SO}_{4}{ }^{2-}$ and $\mathrm{NH}_{4}{ }^{+} / \mathrm{NO}_{3}{ }^{-}$is a possible indicator of $\mathrm{NH}_{4} \mathrm{NO}_{3}$ and $\left(\mathrm{NH}_{4}\right)_{2} \mathrm{SO}_{4}$ (Seinfeld 1986). Elevated values of the $\mathrm{SO}_{4}{ }^{2}$ ${ }^{-} / \mathrm{NO}_{3}{ }^{-}$ratio showed an excess of sulfate over nitrate, values ranging between 26.47 and 68.31, indicating anthropogenic sources in the atmospheric precipitation of industrial areas (Migliavacca et al. 2005). Use of fertilizers containing $\left(\mathrm{NH}_{4}\right)_{2} \mathrm{SO}_{4}$ and $\mathrm{NH}_{4} \mathrm{NO}_{3}$ can be converted into $\mathrm{NH}_{3}$, which in the atmosphere can act as a neutralizing agent (Al-Momani et al. 1995a; Kaya and Tuncel 1997; Seinfield and Pandis 1998; Migliavacca et al. 2005).

\section{Wet deposition rates of major ions and heavy metals}

Wet deposition is an effective route of pollutants removal from the atmosphere, while quantitative measurement of wet deposition helps to identify the relative contributions of the various 
Table 2 Neutralization factors of the major ions and AP/NP ratio in rainwater samples

\begin{tabular}{|c|c|c|c|c|c|c|}
\hline & $\mathrm{NF}_{\mathrm{NH} 4}$ & $\mathrm{NF}_{\mathrm{Ca}}$ & $\mathrm{NF}_{\mathrm{Na}}$ & $\mathrm{NF}_{\mathrm{K}}$ & $\mathrm{NF}_{\mathrm{Mg}}$ & $\mathrm{AP} / \mathrm{NP}$ \\
\hline \multicolumn{7}{|l|}{$\mathrm{RS}$} \\
\hline Mean value & 1.51 & 2.16 & 0.61 & 0.23 & 1.01 & 0.31 \\
\hline St. dev. & 1.12 & 1.62 & 0.75 & 0.29 & 0.94 & 0.31 \\
\hline Range & $0.01-5.74$ & $0.04-8.67$ & $0.03-4.45$ & $0.01-1.27$ & $0.03-4.15$ & $0.06-1.92$ \\
\hline \multicolumn{7}{|l|}{$\mathrm{MN}$} \\
\hline Mean value & 0.60 & 1.56 & 0.13 & 0.10 & 0.77 & 0.54 \\
\hline St. dev. & 0.50 & 1.17 & 0.13 & 0.10 & 0.81 & 0.39 \\
\hline Range & $0.03-2.39$ & $0.21-5.57$ & $0.02-0.81$ & $0.01-0.54$ & $0.03-3.08$ & $0.14-1.65$ \\
\hline \multicolumn{7}{|l|}{$\mathrm{BH}$} \\
\hline Mean value & 0.52 & 1.73 & 0.14 & 0.09 & 0.99 & 0.61 \\
\hline St. dev. & 0.62 & 1.58 & 0.12 & 0.07 & 1.33 & 0.57 \\
\hline Range & $0.02-3.35$ & $0.18-9.60$ & $0.02-0.61$ & $0.01-0.29$ & $0.03-9.20$ & $0.05-2.27$ \\
\hline
\end{tabular}

natural and anthropogenic sources (Tiwari et al. 2016). The annual wet deposition (WD) flux is expressed in $\mathrm{kg} \mathrm{ha}^{-1}$ year $^{-1}$, and is calculated taking under consideration the VWM (mg/L) and the annual rainfall (RF) amount, using the following equation:

$\mathrm{WD}\left(\mathrm{kgha}^{-1} \mathrm{yr}^{-1}\right)=\mathrm{VWM}\left(\mathrm{mg} \mathrm{L}^{-1}\right) \times \frac{\mathrm{RF}}{100}$

The multi-annual WD in precipitation over the 4-year period (2014-2017) at the sampling sites of RS, MN, and BH is displayed in Fig. 3 and varied from site to site due to different precipitation amounts and different influences of major ion and heavy metal sources.

In the case of heavy metals, $\mathrm{Cd}$ had the highest wet deposition rates, $0.04 \mathrm{~kg} \mathrm{ha}^{-1}$ year $^{-1}$ at $\mathrm{MN}$ and $0.07 \mathrm{~kg} \mathrm{ha}^{-1}$ year $^{-1}$ at BH. In the case of $\mathrm{Pb}$, the most elevated values were also observed at $\mathrm{MN}$ and $\mathrm{BH}$, presenting $0.02 \mathrm{~kg} \mathrm{ha}^{-1}$ year $^{-1}$ and $0.03 \mathrm{~kg} \mathrm{ha}^{-1}$ year $^{-1}$, respectively. $\mathrm{Ni}$ and As had insignificant wet deposition fluxes. WD fluxes for acidic species, such as $\mathrm{SO}_{4}{ }^{2}$ and $\mathrm{Cl}^{-}$, were the highest when the precipitation amount increased, while in the case of lower precipitation amounts, alkaline species had lower WD rates (Tiwari et al. 2016). The highest multi-annual mean WD flux for both anions and cations was measured at $\mathrm{BH}$, deposition rates here being with $\sim 33 \%$ and $147 \%$ greater than at MN and RS, respectively. The highest WD flux for $\mathrm{SO}_{4}{ }^{2-}\left(125.86 \mathrm{~kg} \mathrm{ha}^{-1}\right.$ year $\left.{ }^{-1}\right)$ and $\mathrm{Cl}^{-}$
(73.75 $\mathrm{kg} \mathrm{ha}^{-1}$ year $^{-1}$ ) was measured at $\mathrm{BH}$, followed by $\mathrm{MN}$ with $67.74 \mathrm{~kg} \mathrm{ha}^{-1}$ year ${ }^{-1}$ for $\mathrm{SO}_{4}{ }^{2-}$ and $39.69 \mathrm{~kg} \mathrm{ha}^{-1}$ year ${ }^{-1}$ for $\mathrm{Cl}^{-}$. In the case of $\mathrm{RS}, \mathrm{Cl}^{-}$had the highest deposition flux, accounting for $26.01 \mathrm{~kg} \mathrm{ha}^{-1}$ year ${ }^{-1}$. Regarding the cations, at all sampling sites, $\mathrm{Ca}^{2+}$ had the highest wet deposition values, being $97.95 \mathrm{~kg} \mathrm{ha}^{-1}$ year $^{-1}, 50.33 \mathrm{~kg} \mathrm{ha}^{-1}$ year $^{-1}$, and $14.63 \mathrm{~kg} \mathrm{ha}^{-1}$ year $^{-1}$ at $\mathrm{BH}, \mathrm{MN}$, and $\mathrm{RS}$, respectively.

The results regarding the WD rates of major ions correlate with the results obtained for NFs, explaining the greater concentration of acidic species at $\mathrm{BH}$ and $\mathrm{MN}$, which may be due to coal combustion and the use of chloride in the metallurgic industry. Another cause of higher wet deposition rate of sulfate is due to the size of this ion in the atmosphere (AlMomani et al. 1995a). Being a secondary particle, this ion is produced by the gas to particle conversion process, leading to the formation of ultrafine particles, which can grow via coagulation (Al-Momani et al. 1995b). Sulfate is removed most efficiently by wet deposition, through the in-cloud scavenging mechanism, causing higher WD rates.

\section{Assessment of ecological risks and potential effects of increased heavy metal concentration}

Trace metals occur in many environmental matrices, and can be naturally found in the Earth's crust (Chubaka et al. 2018). According to the World Health Organization (WHO) $\mathrm{Pb}, \mathrm{Cd}$, $\mathrm{As}$, and $\mathrm{Ni}$ are classified as highly toxic to humans.

Table 3 Ionic ratios among measured ions

\begin{tabular}{|c|c|c|c|c|c|c|c|}
\hline & $\frac{\mathrm{H}^{+}}{\mathrm{NO}_{3}^{-}+\mathrm{SO}_{4}^{2-}}$ & $\frac{\mathrm{SO}_{4}^{2-}}{\mathrm{NO}_{3}^{-}}$ & $\frac{\mathrm{NH}_{4}^{+}}{\mathrm{NO}_{3}^{-}}$ & $\frac{\mathrm{NH}_{4}^{+}}{\mathrm{SO}_{4}^{2-}}$ & $\frac{\mathrm{Ca}^{2+}+\mathrm{Mg}^{2+}+\mathrm{NH}_{4}^{+}}{\mathrm{NO}_{3}^{-}+\mathrm{SO}_{4}^{2-}}$ & $\frac{\mathrm{NO}_{3}^{-}+\mathrm{Cl}^{-}}{\mathrm{SO}_{4}^{2-}}$ & $\frac{\mathrm{NO}_{3}^{-}+\mathrm{SO}_{4}^{2-}}{\mathrm{Ca}^{2+}+\mathrm{Mg}^{2+}}$ \\
\hline RS & 0.08 & 26.47 & 36.30 & 2.35 & 4.68 & 3.72 & 0.79 \\
\hline $\mathrm{MN}$ & 0.002 & 35.94 & 15.61 & 0.68 & 2.93 & 1.02 & 0.90 \\
\hline BH & 0.001 & 68.31 & 22.44 & 0.55 & 3.23 & 0.98 & 1.00 \\
\hline
\end{tabular}


Fig. 3 The average multi annual wet flux depositions ( $\mathrm{kg} \mathrm{ha}^{-}$ ${ }^{1}$ year $^{-1}$ ) of major ions at the studied sampling sites
1000.000

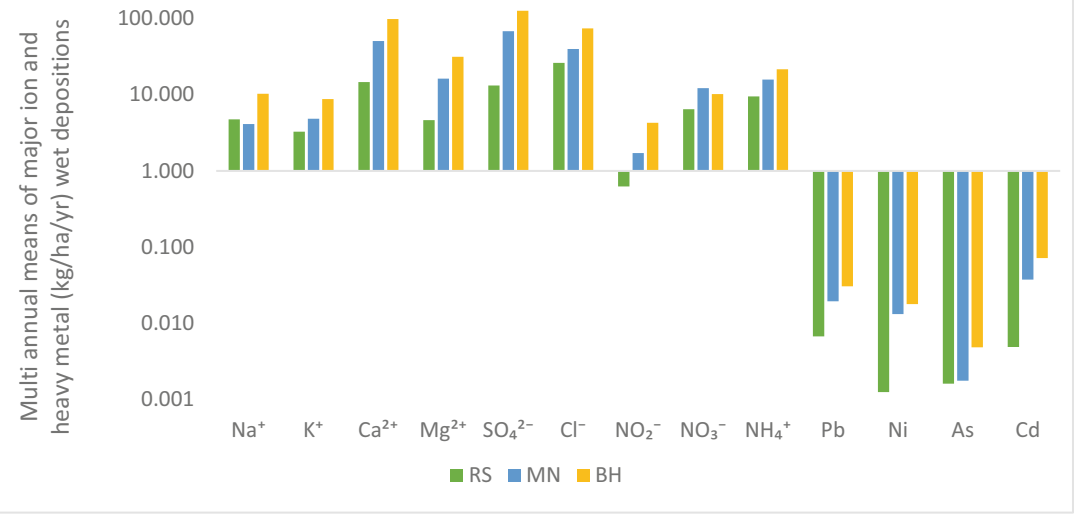

Concentrations of these metals can also be found in rainwater, and are emitted to the atmosphere from metal smelters and waste processing plants, but mining and industrial activities also play a significant role in increasing the concentrations of these metals in the environment (Morais et al. 2012; Malassa et al. 2014; Chubaka et al. 2018). High concentrations of heavy metals deposited into common sources of drinking water, such as lakes and streams. can increase the concentrations of these metals above the acknowledged safety limits, affecting the ecosystem, humans or other organisms (Galloway et al. 1982). The toxicity potential (TP) of rainwater chemistry and of heavy metals in wet deposition can be calculated using the recommended upper limits for metal concentrations to observed median values in wet deposition (Galloway et al. 1982):

$\mathrm{TP}=\frac{\text { Concentration of metal in wet deposition }}{\text { Recommended upper limits for metal concentration }}$

TP values $>1$ imply potential toxic deposition. In order to define the toxicity potential of wet deposited heavy metals from rainwater, the maximum contaminant level (MCL) value was used. According to the Drinking Water Standards and Health Advisories (USEPA 2012), MCL represents the highest level of a contaminant that is allowed in drinking water. This value is $0.015 \mathrm{mg} / \mathrm{L}, 0.005 \mathrm{mg} / \mathrm{L}$, and $0.01 \mathrm{mg} / \mathrm{L}$ for $\mathrm{Pb}, \mathrm{Cd}$, and $\mathrm{As}$, respectively. $\mathrm{Ni}$ does not have a MCL values, but according to Chubaka et al. (2018), the health limit for $\mathrm{Ni}$ is $0.02 \mathrm{mg} / \mathrm{L}$. Results have shown that $\mathrm{Cd}$ had the highest values at all sampling sites (Table 4), at MN and $\mathrm{BH}$, the TP being 7 and 14 times higher than the reference value, respectively. $\mathrm{Pb}$ also exhibited higher values than 1 at $\mathrm{MN}$ and $\mathrm{BH}$, suggesting a potential toxicity, as for As and $\mathrm{Ni}$, values were much lower. TP values $>1$ in the case of $\mathrm{MN}$ and $\mathrm{BH}$ are suggesting an elevated risk for human health in case of rainwater ingestion, especially in rural areas, where harvested rainwater is still used in households, but in order to establish if heavy metals concentration found in rainwater is affecting human health additional research is mandatory.

In order to further evaluate the contamination of precipitation, the contamination factor and the contamination degree were calculated. Results are shown in Table 5. The contamination factor represents the ratio between the concentration of heavy metal measured in rainwater divided by the background value for the respective metal (Liu et al. 2005):

$C_{\mathrm{f}}^{\mathrm{i}}=\frac{C_{\mathrm{i}}}{C_{\mathrm{b}}}$

where $C_{\mathrm{i}}$ is the concentration of an individual metal measured in rainwater, while $C_{\mathrm{b}}$ represents the background concentration calculated for the individual metal. The background value of each metal was determined using the relationship between statistical estimators (mean $\pm 2 \sigma$ ), after extreme values were removed from the dataset, in order to assure the correctness and the applicability of this method (Reimann et al. 2005; Hernández-Crespo and Martín 2015).

The contamination degree can be calculated by summing all contamination factors for all metals (Liu et al. 2005):

$C_{\mathrm{d}}=\sum_{\mathrm{i}=1}^{\mathrm{n}} C_{\mathrm{f}}^{\mathrm{i}}$

The method described above was also used by Hakanson (1980) and Luo et al. (2007) to calculate the soil contamination. This work uses the same method, but it was adapted to
Table 4 Toxicity potential for heavy metals in wet deposition

\begin{tabular}{lllll}
\hline & $\mathrm{Pb}$ & $\mathrm{Ni}$ & $\mathrm{As}$ & $\mathrm{Cd}$ \\
\hline $\mathrm{RS}$ & 0.45 & 0.06 & 0.16 & 0.98 \\
$\mathrm{MN}$ & 1.3 & 0.66 & 0.18 & 7.49 \\
$\mathrm{BH}$ & 2.04 & 0.89 & 0.48 & 14.33 \\
\hline
\end{tabular}


Table 5 Contamination factors and contamination degree of heavy metal concentrations in rainwater

\begin{tabular}{llllll}
\hline & \multicolumn{2}{l}{ Contamination factor $\left(C_{f}^{i}\right)$} & & Contamination degree $\left(C_{\mathrm{d}}\right)$ \\
\cline { 2 - 5 } & $\mathrm{Pb}$ & $\mathrm{Ni}$ & $\mathrm{As}$ & $\mathrm{Cd}$ & \\
\hline $\mathrm{RS}$ & 2.53 & -5.86 & 2.57 & 5.16 & 4.39 \\
$\mathrm{MN}$ & 2.74 & -0.72 & 3.68 & 1.54 & 7.24 \\
$\mathrm{BH}$ & 3.90 & -1.13 & 2.22 & 1.20 & 6.19 \\
\hline
\end{tabular}

assess the contamination with heavy metals in rainwater. According to Hakanson (1980), four categories of $C_{\mathrm{f}}^{\mathrm{i}}$ and four categories of $C_{\mathrm{d}}$ can be defined. Regarding contamination factors, a value $<1$ indicates low contamination, values between 1 and 3 are known as moderate, $3 \leq C_{\mathrm{f}}^{\mathrm{i}}<6$ indicates considerable, while values $>6$ are a sign of a very high contamination. The classes defined for $C_{\mathrm{d}}$ are the same, but having different intervals: $C_{\mathrm{d}}<5$-low contamination, $5 \leq C_{\mathrm{d}}<$ 10 -moderate contamination, $10 \leq C_{\mathrm{d}}<20$ considerable contamination, while with values $>20$ represent a high level of contamination (Hakanson 1980).

Based on the individual contamination factor of heavy metal concentration, rainwater collected at RS was moderately contaminated with $\mathrm{Pb}$ and considerably contaminated with $\mathrm{Cd}$. Precipitation samples collected at MN were found to be moderately contaminated with $\mathrm{Pb}$ and $\mathrm{Cd}$, while contamination with $\mathrm{As}$ is considerable. Contamination factors for $\mathrm{BH}$ showed that rainwater is slightly contaminated with As and $\mathrm{Cd}$, while the $C_{\mathrm{f}}^{\mathrm{i}}$ for $\mathrm{Pb}$ posed as considerable. The overall precipitation contamination with heavy metals at the three sampling sites was assessed by the degree of contamination, which showed that precipitation at $\mathrm{MN}$ and $\mathrm{BH}$ is considerably contaminated, while at $\mathrm{RS}$, the $C_{\mathrm{d}}$ lies within the class of moderate contamination.

\section{Origins of major ions in rainwater}

\section{Marine and non-marine influence and their relationship with atmospheric circulations}

In order to assess the main sources of chemical compositions in rainwater, including sea salts, terrestrial dust from wind erosion, mining, biogenic material, and various anthropogenic activities, enrichment factors (EFs), sea salt fractions (SSF), and non-sea salt fractions (NSSF) were calculated. Enrichment factors are usually used to investigate the potential sources of elements in rainwater (Okay et al. 2002; Cao et al. 2009; Wu et al. 2016). Since $\mathrm{Na}^{+}$is known to be the best tracer for seawater, and assuming all $\mathrm{Na}^{+}$is of marine origin, it was used as reference element. In order to calculate the EF values and to quantify the sea salt (SSF) and non-sea salt (NSSF) contributions to rainwater, the following equations were used (Keene et al. 1986; Kulshrestha et al. 1996; Conradie et al. 2016):
Enrichemen Factor $(X)=\frac{(X / \mathrm{Na})_{\text {rain }}}{(X / \mathrm{Na})_{\text {sea }}}$

$\% \mathrm{SSF}=\frac{100 \times(\mathrm{Na})_{\text {rain }} \times(X / \mathrm{Na})_{\text {sea }}}{(X)_{\text {rain }}}$

$\% N S S F=100-\mathrm{SSF}$

where $X$ is the concentration of the respective ion. The results are shown in Table 6 . The enrichment factor is often used to differentiate aerosol sources, if the EF value is much smaller than 1 or much greater than 1 is considered concentrated or diluted relative to the reference source (Okay et al. 2002; Wu et al. 2016). EF values for $\mathrm{K}^{+}, \mathrm{Ca}^{2+}, \mathrm{Mg}^{2+}$, and $\mathrm{SO}_{4}{ }^{2-}$ were significantly higher than one, reflecting strong terrestrial influence, while although EF values for $\mathrm{Cl}^{-}$were higher than 1, but still much lower than the EF values for the other ions, it can indicate a small contribution from seawater (Wu et al. 2016).

The average values of ionic ratios of $\mathrm{Cl}^{-}, \mathrm{K}^{+}, \mathrm{Ca}^{2+}, \mathrm{Mg}^{2+}$, and $\mathrm{SO}_{4}{ }^{2-}$ with respect to $\mathrm{Na}^{+}$in rainwater were calculated and compared with the respective ratios in seawater. The much higher ionic ratio values found for rainwater suggest the strong contribution of other sources, such as local natural emissions, soil dust, and anthropogenic activities (Samara and Tsitouridou 2000). The results for SSFs and NSSFs at all sampling sites show that all $\mathrm{Cl}^{-}, \mathrm{K}^{+}, \mathrm{Ca}^{2+}, \mathrm{Mg}^{2+}$, and $\mathrm{SO}_{4}{ }^{2-}$ mainly have non-marine origins. In the case of $\mathrm{Cl}^{-}$, the highest SSF was estimated at RS, $\sim 35 \%$. The chloride non-sea salt fraction could be attributed to various anthropogenic activities, such as automobile exhaust and iron and steel production (Xu et al. 2009; Wu et al. 2016).

Dissolution of evaporite minerals, such as halite and sylvite, from soil dust can be attributed as natural sources to NSSF Cl${ }^{-}$ (Xu et al. 2009). $\mathrm{SO}_{4}{ }^{2-}$ showed the high dominance of nonmarine source, with a NSSF value of $92.19 \%, 98.12 \%$, and $98.56 \%$ at $\mathrm{RS}, \mathrm{MN}$, and $\mathrm{BH}$, respectively. These values are representing anthropogenic origin, related to the considerable energy consumption, coal combustion, and high industrialization rate in the studied areas. $\mathrm{K}^{+}, \mathrm{Ca}^{2+}$, and $\mathrm{Mg}^{2+}$ are all originated from terrestrial sources, resulting from soil dust from the un-rehabilitated tailing dams and from the dissolution of dolomite limestones, fertilizers, and agricultural activities.

These results are also sustained by the weak correlations between $\mathrm{Na}^{+}$and $\mathrm{Cl}^{-}$indicating fractionation of sea salt and 
Table 6 Equivalent ratios of different components with reference to $\mathrm{Na}^{+}$in rainwater

\begin{tabular}{|c|c|c|c|c|c|}
\hline & $\frac{\mathrm{Cl}^{-}}{\mathrm{Na}^{+}}$ & $\frac{\mathrm{K}^{+}}{\mathrm{Na}^{+}}$ & $\frac{\mathrm{Ca}^{2+}}{\mathrm{Na}^{+}}$ & $\frac{\mathrm{Mg}^{2+}}{\mathrm{Na}^{+}}$ & $\frac{\mathrm{SO}_{4}^{2-}}{\mathrm{Na}^{+}}$ \\
\hline Seawater & 1.16 & 0.02 & 0.04 & 0.22 & 0.12 \\
\hline \multicolumn{6}{|l|}{ RS } \\
\hline Mean value (rainwater) & 6.35 & 0.50 & 6.30 & 3.05 & 2.55 \\
\hline$\% \mathrm{SSF}$ & 34.91 & 5.20 & 1.08 & 12.26 & 7.81 \\
\hline$\% \mathrm{NSSF}$ & 65.09 & 94.80 & 98.92 & 87.74 & 92.19 \\
\hline$\% \mathrm{EF}$ & 5.48 & 22.87 & 143.27 & 13.45 & 20.38 \\
\hline \multicolumn{6}{|l|}{$\mathrm{MN}$} \\
\hline Mean value (rainwater) & 8.06 & 0.93 & 17.53 & 9.43 & 10.88 \\
\hline$\% \mathrm{SSF}$ & 26.77 & 3.57 & 0.43 & 3.94 & 1.88 \\
\hline$\% \mathrm{NSSF}$ & 73.23 & 96.43 & 99.57 & 96.06 & 98.12 \\
\hline$\% \mathrm{EF}$ & 6.95 & 42.12 & 398.44 & 41.56 & 87.02 \\
\hline \multicolumn{6}{|l|}{$\mathrm{BH}$} \\
\hline Mean value (rainwater) & 7.91 & 0.91 & 18.60 & 9.47 & 12.02 \\
\hline$\% \mathrm{SSF}$ & 20.23 & 3.28 & 0.31 & 3.20 & 1.44 \\
\hline$\%$ NSSF & 79.77 & 96.72 & 99.69 & 96.80 & 98.56 \\
\hline$\% \mathrm{EF}$ & 6.82 & 41.29 & 422.75 & 41.72 & 96.13 \\
\hline
\end{tabular}

modification by non-marine constituents (Tables 7, 8, and 9), as the sampling sites are approximately $540 \mathrm{~km}$ away from the Adriatic Sea and $1240 \mathrm{~km}$ away from the Mediterranean Sea. The Foehn effect also has a significant contribution to the presence of weak correlations between sodium and chloride.

In order to better explain the lack of marine influences, and to track the sea salt transport and sea humidity, we analyzed the distribution of rainfall quantities (Fig. 4) upon the Balkan peninsula recorded during the occurrence of cyclonic circulations in the eastern Mediterranean basin (Fig. 5) for the 19792018 period.

Usually, these synoptic patterns consist into frontal passages moving from northern Europe towards the Mediterranean Sea. When these fronts reach southern Europe (usually the vicinity of the Gulf of Genova), they often lead to cyclogenesis, enhancing the existent baroclinic conditions. The cyclones born in this area usually follow a west to east trajectory, across the Dinaric Alps towards the Balkans inland. As they travel towards the east, their humidity content is constantly decreasing due to the orographic barrier imposed by the high elevated terrain in this area. In terms of absolute frequency, these synoptic types are more frequent in the winter, spring, and autumn and less in the summertime, when anticyclonic conditions are usually prevalent upon Europe (Fig. 6).

As a result of the orographic lifting, the sea salts concentration in the precipitation is affected due to the adiabatic processes on the windward slopes of Dinaric Alps. This also has effects upon the temperature in the air mass since the descending air on the leeward side will be warmer and subsequently drier due to the adiabatic compression.

\section{Crustal enrichment factor}

The assessment of crustal enrichment factor $\left(\mathrm{EF}_{\mathrm{c}}\right)$ represents a simple and useful way to characterize the elements in rainwater, taking under account their degree of perturbation relative to soil-originated elements (Uygur et al. 2010). In order to estimate the $\mathrm{EF}_{\mathrm{c}}$ of different trace elements in rainwater, the following equation was used, considering $\mathrm{Mg}^{2+}$ as a reference element (Cao et al. 2009; Facchini Cerqueira et al. 2014):

$\mathrm{EF}_{\mathrm{c}}=\left[X / \mathrm{Mg}^{2+}\right]_{\text {rainwater }} /\left[X / \mathrm{Mg}^{2+}\right]_{\text {crust }}$

where $X$ is the concentration of the element of interest in the rainwater sample, $X / \mathrm{Mg}^{2+}$ of rainwater is the ratio from rainwater composition, and $X / \mathrm{Mg}^{2+}$ of crust represents the ratio of crustal composition (Báez et al. 2007; Barbalace 2015). Resulted values of $\mathrm{EF}_{\mathrm{c}}$ are given in Fig. 7.

An $\mathrm{EF}_{\mathrm{c}}$ value close to unity indicates that the only source of that element to be soil derived, while values much higher than 1 are suggesting the influence of other sources too, other than the earth's crust (Başak and Alagha 2004). According to Poissant et al. (1994), regarding heavy metals enrichment, due to local variations in the earth's crust composition, a limit of 10 rather than 1 is considered acceptable for crustal material. In this case, elements with an $\mathrm{EF}_{\mathrm{c}}$ value between 10 and 500 are considered moderately enriched, indicating additional sources to the crustal origin, while an $\mathrm{EF}_{\mathrm{c}}$ greater than 500 suggests heavily enriched state, referring to a severe contamination due to anthropogenic activities (Poissant et al. 1994). 
Table 7 Spearman correlation coefficients for ionic constituents and trace elements in precipitation

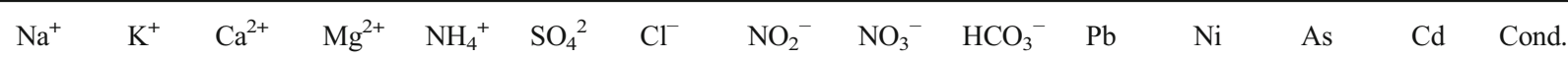

RS

$\mathrm{Na}^{+} \quad 1$

$\begin{array}{ccc}\mathrm{K}^{+} & 0.53 & 1\end{array}$

$\begin{array}{llll}\mathrm{Ca}^{2+} & 0.28 & 0.43 & 1\end{array}$

$\begin{array}{lllll}\mathrm{Mg}^{2+} & 0.14 & 0.32 & 0.77 & 1\end{array}$

$\begin{array}{llllll}\mathrm{NH}_{4}^{+} & 0.11 & 0.41 & 0.39 & 0.33 & 1\end{array}$

$\begin{array}{llllll}\mathrm{SO}_{4}{ }^{2-} & 0.37 & 0.39 & 0.47 & 0.34 & 0.35\end{array}$

$\begin{array}{llllllll}\mathrm{Cl}^{-} & 0.13 & 0.10 & 0.34 & 0.32 & 0.12 & 0.31 & 1\end{array}$

$\begin{array}{lllllllll}\mathrm{NO}_{2}{ }^{-} & 0.27 & 0.25 & 0.24 & 0.15 & 0.27 & 0.35 & 0.19 & 1\end{array}$

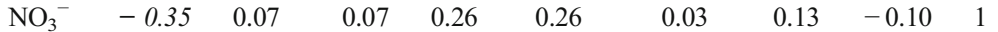

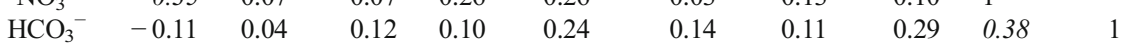

$\begin{array}{lllllllllll}\mathrm{Pb} & 0.14 & 0.26 & 0.16 & 0.66 & 0.35 & 0.58 & 0.53 & -0.38 & 0.40 & -0.23\end{array}$

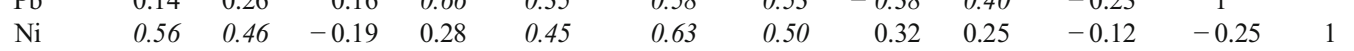

$\begin{array}{llllllllllllll}\text { As } & 0.27 & 0.03 & 0.52 & 0.20 & 0.30 & -0.05 & -0.32 & -0.01 & 0.19 & 0.20 & 0.20 & -0.22 & 1\end{array}$

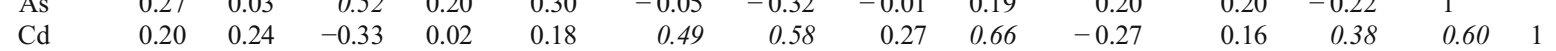

$\begin{array}{lllllllllllllllll}\text { Cond. } & 0.36 & 0.62 & 0.57 & 0.48 & 0.49 & 0.68 & 0.29 & 0.37 & 0.18 & 0.35 & 0.42 & 0.07 & -0.40 & 0.19 & 1\end{array}$

$\mathrm{MN}$

$\mathrm{Na}^{+} \quad 1$

$\mathrm{K}^{+} \quad 0.56 \quad 1$

$\mathrm{Ca}^{2+} \quad 0.30 \quad 0.17 \quad 1$

$\begin{array}{lllll}\mathrm{Mg}^{2+} & 0.32 & 0.14 & 0.78 & 1\end{array}$

$\begin{array}{llllll}\mathrm{NH}_{4}{ }^{+} & 0.04 & 0.21 & 0.32 & 0.31 & 1\end{array}$

$\begin{array}{lllllll}\mathrm{SO}_{4}{ }^{2-} & 0.58 & 0.35 & 0.42 & 0.40 & 0.22 & 1\end{array}$

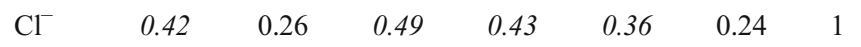

$\begin{array}{lllllllll}\mathrm{NO}_{2}^{-} & 0.12 & 0.16 & 0.21 & 0.20 & 0.71 & 0.27 & 0.04 & 1\end{array}$

$\begin{array}{llllllllll}\mathrm{NO}_{3}{ }^{-} & -0.09 & 0.05 & 0.29 & 0.27 & -0.16 & -0.04 & -0.06 & -0.39 & 1\end{array}$

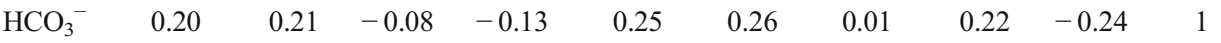

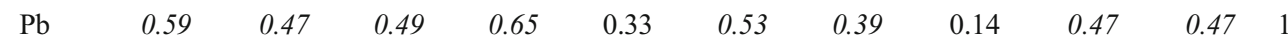

$\begin{array}{lllllllllllll}\mathrm{Ni} & 0.73 & 0.54 & 0.63 & 0.64 & 0.29 & 0.78 & 0.41 & -0.21 & 0.51 & 0.10 & 0.17 & 1\end{array}$

$\begin{array}{llllllllllllll}\text { As } & 0.20 & 0.02 & 0.57 & 0.36 & 0.08 & 0.50 & 0.44 & 0.11 & -0.50 & 0.61 & 0.46 & 0.02 & 1\end{array}$

$\begin{array}{lllllllllllllll}\mathrm{Cd} & 0.78 & 0.27 & 0.51 & 0.89 & 0.53 & 0.73 & 0.28 & 0.34 & -0.45 & 0.12 & 0.62 & 0.27 & 0.40 & 1\end{array}$

$\begin{array}{llllllllllllllll}\text { Cond. } & 0.45 & 0.37 & 0.45 & 0.46 & 0.22 & 0.87 & 0.37 & 0.15 & 0.14 & 0.22 & 0.45 & 0.58 & 0.53 & 0.67 & 1\end{array}$

$\mathrm{BH}$

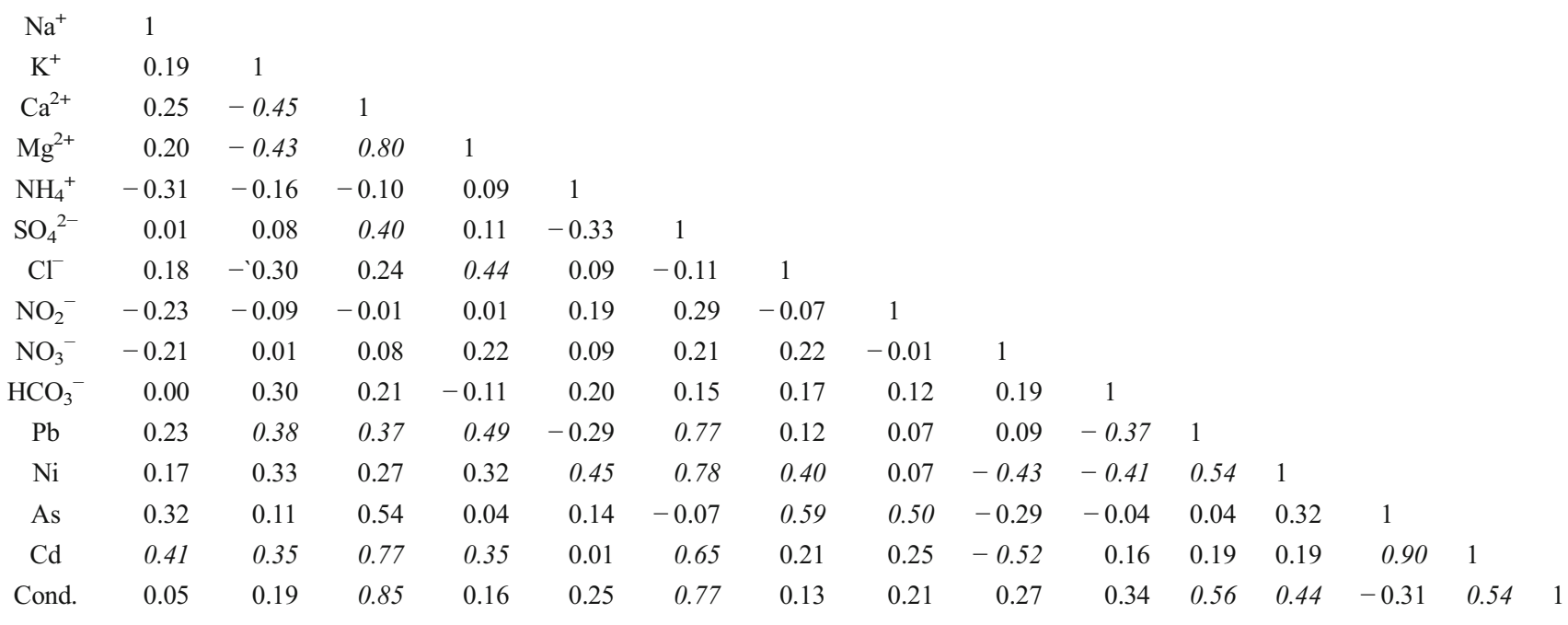

Values with $\mathrm{R}>0.35$ were considered significant at $99 \%$ confidence level 
Table 8 Varimax rotated factor loadings, total variance, and ionic sources at the studied sampling sites

\begin{tabular}{|c|c|c|c|c|}
\hline $\mathrm{RS}$ & F1 & $\mathrm{F} 2$ & F3 & F4 \\
\hline $\mathrm{Na}^{+}$ & .041 & .274 & .384 & -.681 \\
\hline $\mathrm{K}^{+}$ & .195 & -.128 & .899 & -.150 \\
\hline $\mathrm{Ca}^{2+}$ & .865 & .291 & .116 & -.127 \\
\hline $\mathrm{Mg}^{2+}$ & .916 & .096 & .063 & .173 \\
\hline $\mathrm{SO}_{4}{ }^{2-}$ & .224 & .729 & .212 & -.336 \\
\hline $\mathrm{Cl}^{-}$ & .261 & .730 & -.099 & .274 \\
\hline $\mathrm{NO}_{3}^{-}$ & .088 & .190 & .135 & .798 \\
\hline $\mathrm{NH}_{4}^{+}$ & -.047 & .494 & .694 & .157 \\
\hline$\%$ Total variance & 21.94 & 19.11 & 19.07 & 17.26 \\
\hline Possible source & Crustal & Anthropogenic & Agricultural & Traffic \\
\hline $\mathrm{MN}$ & $\mathrm{F} 1$ & $\mathrm{~F} 2$ & F3 & $\mathrm{F} 4$ \\
\hline $\mathrm{Na}^{+}$ & .134 & .515 & .575 & .374 \\
\hline $\mathrm{K}^{+}$ & .063 & .007 & .048 & .976 \\
\hline $\mathrm{Ca}^{2+}$ & .758 & -.038 & .327 & .069 \\
\hline $\mathrm{Mg}^{2+}$ & .896 & -.084 & .006 & .083 \\
\hline $\mathrm{SO}_{4}{ }^{2-}$ & .699 & .188 & .144 & -.004 \\
\hline $\mathrm{Cl}^{-}$ & .219 & -.203 & .881 & -.013 \\
\hline $\mathrm{NO}_{3}^{-}$ & .363 & .736 & .014 & .021 \\
\hline $\mathrm{NH}_{4}^{+}$ & .321 & -.752 & .199 & .034 \\
\hline$\%$ Total variance & 27.15 & 18.23 & 15.97 & 13.82 \\
\hline Possible source & Mixed/crustal & Anthropogenic & Marine & Agricultural \\
\hline $\mathrm{BH}$ & $\mathrm{F} 1$ & $\mathrm{~F} 2$ & F3 & F4 \\
\hline $\mathrm{Na}^{+}$ & -.132 & .359 & .767 & -.227 \\
\hline $\mathrm{K}^{+}$ & -.447 & .662 & .214 & .067 \\
\hline $\mathrm{Ca}^{2+}$ & .829 & -.123 & .223 & .075 \\
\hline $\mathrm{Mg}^{2+}$ & .803 & -.205 & .079 & .082 \\
\hline $\mathrm{SO}_{4}{ }^{2-}$ & .762 & .433 & -.159 & -.135 \\
\hline $\mathrm{Cl}^{-}$ & .317 & -.182 & .795 & .177 \\
\hline $\mathrm{NO}_{3}^{-}$ & .063 & .832 & -.018 & .036 \\
\hline $\mathrm{NH}_{4}^{+}$ & .030 & .066 & -.016 & .973 \\
\hline$\%$ Total variance & 27.95 & 19.28 & 16.86 & 12.33 \\
\hline Possible source & Mixed/crustal & Anthropogenic & Marine & Agricultural \\
\hline
\end{tabular}

The italicized values represent the segnificant factor loadings

Enrichment factors for $\mathrm{Ca}^{2+}$ at all sampling sites, for $\mathrm{Ni}$ at $\mathrm{RS}$ and $\mathrm{MN}$ for $\mathrm{Na}$ at $\mathrm{RS}$, are $<1$, suggesting that these elements have a significant crustal source, being referred to as non-enriched. $\mathrm{Na}^{+}$and $\mathrm{K}^{+}$were moderately enriched, while values greater than 10 for $\mathrm{Pb}$ and $\mathrm{As}$ indicated a considerable enrichment. Values for $\mathrm{Cd}$ exceeded the 500 limit 2 times, 4 times, and 20 times at $\mathrm{RS}, \mathrm{MN}$, and $\mathrm{BH}$, respectively, indicating a severe pollution, this element being anomalously enriched and having a non-crustal source (Báez et al. 2007).

$\mathrm{Pb}$ and $\mathrm{Cd}$ originate primarily from a variety of anthropogenic sources, mining activities, and also the un-rehabilitated tailing dams. $\mathrm{K}^{+}$is usually attributed to terrigenous sources, but a significant concentration of this element in the atmosphere and rainwater can also result from biomass burning and the excessive use of fertilizers. According to Uygur et al. (2010), the degree of enrichment is mainly influenced by the type, proximity, and the extent of individual sources.

\section{Correlation factors}

The chemical composition of rainwater is significantly influenced by the chemical composition of the atmosphere. In order to determine the relationships between ionic species, trace elements, and their provenience from different sources, Spearman's correlation rank among the ions and heavy metals in the rainwater of the three sampling sites was calculated and is shown in Table 7. Only correlations with $R>0.35$ were considered significant at $99 \%$ confidence level. 
Table 9 Varimax-rotated factor loadings, total variance and possible sources of heavy metals in RS, MN and BH rainwater

\begin{tabular}{|c|c|c|c|}
\hline RS & F1 & $\mathrm{F} 2$ & F3 \\
\hline $\mathrm{Pb}$ & .033 & .155 & .987 \\
\hline $\mathrm{Ni}$ & .877 & -.432 & -.052 \\
\hline As & .005 & .969 & .178 \\
\hline $\mathrm{Cd}$ & .895 & .383 & .108 \\
\hline$\%$ Total variance & 39.28 & 32.42 & 25.53 \\
\hline Possible source & Coal combustion & Smelters & Non-ferrous metal production/combustion \\
\hline MN & F1 & $\mathrm{F} 2$ & $\mathrm{~F} 3$ \\
\hline $\mathrm{Pb}$ & .171 & .049 & .983 \\
\hline $\mathrm{Ni}$ & .939 & .035 & .231 \\
\hline As & .176 & .980 & .049 \\
\hline $\mathrm{Cd}$ & .915 & .297 & .062 \\
\hline$\%$ Total variance & 44.51 & 26.33 & 25.65 \\
\hline Possible source & Coal combustion & Smelters & Non-ferrous metal production/combustion \\
\hline $\mathrm{BH}$ & F1 & $\mathrm{F} 2$ & F3 \\
\hline $\mathrm{Pb}$ & .120 & .167 & .978 \\
\hline $\mathrm{Ni}$ & .234 & .954 & .165 \\
\hline As & .758 & .561 & .263 \\
\hline $\mathrm{Cd}$ & .977 & -.155 & -.064 \\
\hline$\%$ Total variance & 39.94 & 31.89 & 26.44 \\
\hline Possible source & Smelters & Oil-fired furnaces & Non-ferrous metal production/combustion \\
\hline
\end{tabular}

The italicized values represent the segnificant factor loadings

The conductivity is a broad indicator of the total dissolved solids in precipitation (Gioda et al. 2013), giving significant correlations with $\mathrm{K}^{+}(0.620-\mathrm{RS}), \mathrm{Ca}^{2+}(0.570-\mathrm{RS}$; 0.449$\mathrm{MN} ; 0.850-\mathrm{BH})$, and $\mathrm{Mg}^{2+}(0.477-\mathrm{RS} ; 0.461-\mathrm{MN})$. In the case of $\mathrm{SO}_{4}{ }^{2-}$, electrical conductivity is well correlated at all sampling sites, showing that probably the below-cloud scavenging mechanism takes place (Rastogi and Sarin 2005). Regarding heavy metals, electrical conductivity presents significant correlations with $\mathrm{Pb}$ at all sampling sites (0.42-RS; $0.45-\mathrm{MN} ; 0.56-\mathrm{BH}$ ), while a strong correlation between As, $\mathrm{Ni}$, and $\mathrm{Cd}$ with electrical conductivity only exists at $\mathrm{MN}$.

The significant correlation between the major exchangeable ions, $\mathrm{Na}^{+}$and $\mathrm{K}^{+}(0.533-\mathrm{RS} ; 0.561-\mathrm{MN})$, may be the result of dissolution/precipitation reactions (Adams et al. 2001). The strong correlation between $\mathrm{Ca}^{2+}$ and $\mathrm{Mg}^{2+}$ at all three sampling sites $(0.77-\mathrm{RS} ; 0.745-\mathrm{GB} ; 0.781-\mathrm{MN} ; 0.803-$ $\mathrm{BH}$ ) implies their common origin (calcite, dolomite, and limestone dissolution, quarries, cement factories), indicating terrestrial sources (Niu et al. 2014; Xiao 2016; Rao et al. 2017). Significant correlation between $\mathrm{Ca}^{2+}$ and $\mathrm{SO}_{4}{ }^{2-}(0.474-\mathrm{RS}$; $0.485-\mathrm{MN} ; 0.401-\mathrm{BH})$ and between $\mathrm{Na}^{+}$and $\mathrm{SO}_{4}{ }^{2-}$ in the case of $\mathrm{MN}(R=0.582)$ shows the contribution of evaporitic salts, such as $\mathrm{CaSO}_{4}$ and $\mathrm{Na}_{2} \mathrm{SO}_{4}$ (Adams et al. 2001). These evaporitic salts are present in the studied area in the form of gypsum, mirabilite, and thernadite, which are signs of volcanic fumaroles and post volcanic activity but are also known as a post-mining precipitate (Stoiber and Rose 1974). Strong significant correlations can be found between $\mathrm{SO}_{4}{ }^{2-}$ and $\mathrm{Pb}$ (0.58-MN; 0.53-MN; 0.77-BH), Ni (0.63-RS; 0.78-MN and $\mathrm{BH})$, and $\mathrm{Cd}(0.49-\mathrm{RS} ; 0.73-\mathrm{MN} ; 0.65-\mathrm{BH})$, which suggests the same source origin, since the studied areas are known for mining activities and the metal industry.

Positive correlations between $\mathrm{Ca}^{2+}, \mathrm{Mg}^{2+}$, and heavy metals can be ascribed to the composition of particulate matter, especially at $\mathrm{MN}$, where the un-rehabilitated tailings dam is creating a constant problem, since thin particles of contaminated dust are carried by the wind to the atmosphere and to the neighboring shore of Serbia, leading to cross-border pollution. The lack and the weak correlations between $\mathrm{Na}^{+}$and $\mathrm{Cl}^{-}$at $\mathrm{RS}, \mathrm{BH}$, and $\mathrm{MN}$, respectively, show that the marine influence on the precipitation chemistry is lower, and that they are emitted from other sources, such as industry or coal combustion (Ruprecht and Sigg 1990; Kaneyasu et al. 1999; Anatolaki and Tsitouridou 2009). The air masses that favor the transport of marine sprays coming from the Mediterranean and Adriatic Sea are obstructed by the Dinaric Alps and by the Balkan Mountains. As discussed earlier, the Foehn effect takes a great role in explaining the lack of correlation between sea salt ions in the rainwater. In the presence of Foehn winds, the air masses coming from the Adriatic Sea are mostly dry, having less humidity, since they are obstructed by the Dinaric Alps, leading to an orographic convection. According to Puxbaum et al. (1993), because $\mathrm{Cl}^{-}$is discussed in relation to $\mathrm{Na}^{+}$as sea salt aerosol, considered to be marine, it is no wonder that there are few studies that discuss the lack of correlation 
Fig. 4 Multi-annual means of precipitation sums according to each cyclonic weather type

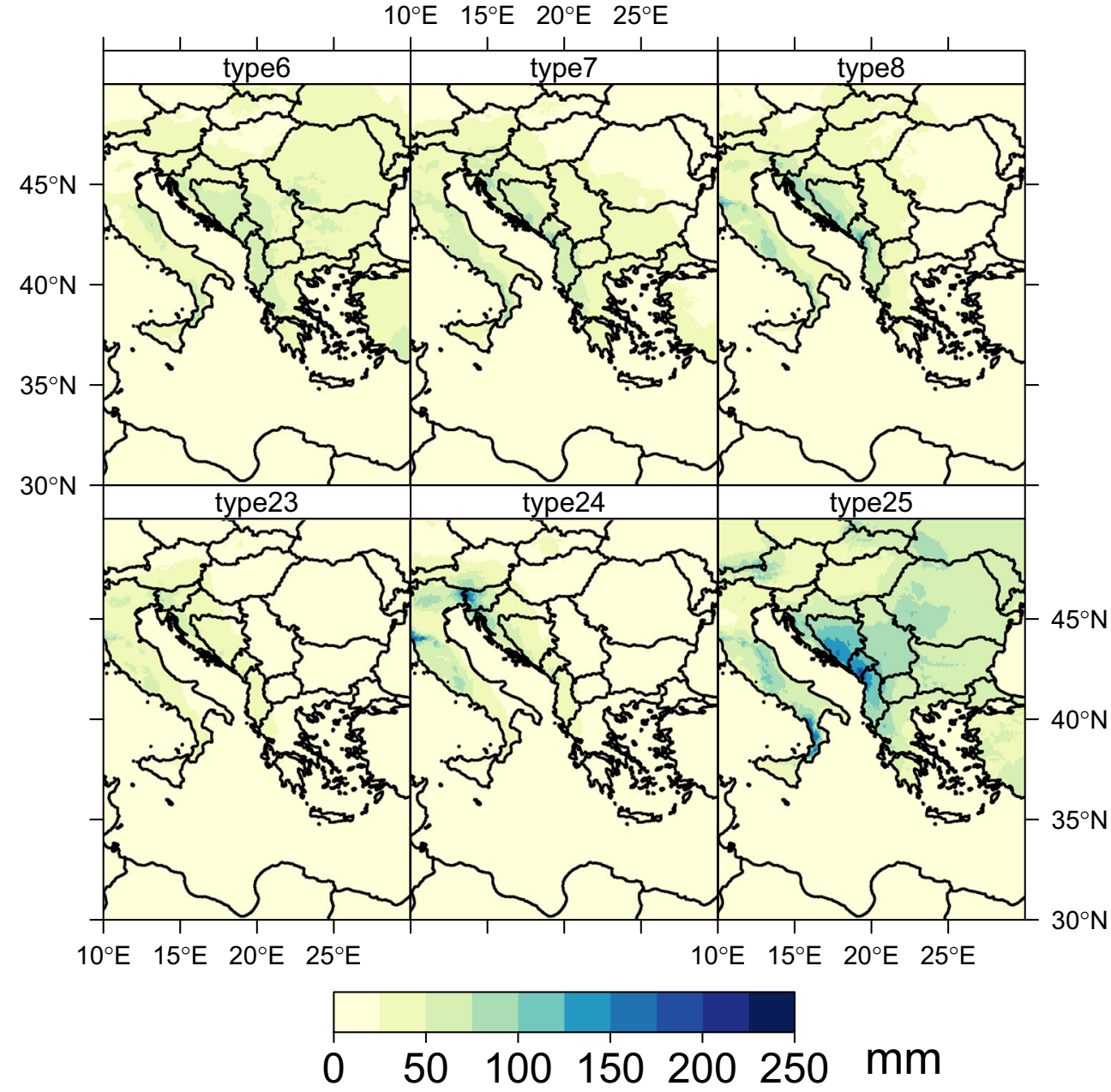

between sodium and chloride, and therefore other origins than marine of chloride concentration in precipitation. Due to their geographical position, since $\mathrm{MN}$ is situated more closely to the Adriatic and Mediterranean Sea, the higher correlation between sodium and chloride can be explained, while the insignificant correlation at $\mathrm{RS}$ and $\mathrm{BH}$ is probably due to the stronger contribution of other local sources. Since in RS a great variability of industrial activities takes place, and $\mathrm{BH}$ is well renowned for its mineral springs, thermal waters, and mofettas, the local emissions and strong influence of chloride concentrations can be explained.

\section{Source identification using principal component analysis}

Another useful tool in determining the origins of major ions in rainwater is the PCA. In the case of ionic species, a total of four factors were extracted, explaining about $77.39 \%$, $75.17 \%$, and $77.42 \%$ of the total variance at $\mathrm{RS}, \mathrm{MN}$, and $\mathrm{BH}$, respectively. Loadings of the Varimax rotated factors for all studied areas for ionic species are presented in Table 8 .

At RS, the rotated component matrix showed that $\mathrm{Ca}^{2+}$ and $\mathrm{Mg}^{2+}$ are associated in the first factor (F1), explaining $21.94 \%$ of the total variance. The main sources for $\mathrm{Ca}^{2+}$ and $\mathrm{Mg}^{2+}$ are terrestrial, resulting from the dissolution of limestones and dolomites (Rao et al. 2016; Tiwari et al. 2016; Xiao 2016). The second factor explained $19.11 \%$ of the total variance and showed high loadings of $\mathrm{SO}_{4}{ }^{2-}$ and $\mathrm{Cl}^{-}$, which can be attributed to anthropogenic sources, since the metallurgic industry which is significant in the studied area is known for coal combustion and use of chloride. F3 represented $19.07 \%$ of the total variance, having high loadings of $\mathrm{K}^{+}$and $\mathrm{NH}_{4}{ }^{+}$, indicating the use of fertilizers and agricultural activities. The association of these two ions is a possible indicator of the use of chemical and natural fertilizers, such as NPK or animal manure. According to Behera et al. (2013), nitrogen is excreted in the form of urea (in mammals) or uric acid (in birds), which through decomposition (vaporization) can form $\mathrm{NH}_{3}$ and $\mathrm{NH}_{4}{ }^{+}$in the atmosphere. Factor 4 has high loadings of $\mathrm{NO}_{3}^{-}$, accounting for $17.26 \%$ of the total variance and can be attributed to traffic emissions and coal burning (Huang et al. 2008).

For $\mathrm{MN}$ and $\mathrm{BH}$, the order of possible sources and the variance of factors are very similar. The first factor at $\mathrm{MN}$ and $\mathrm{BH}$ accounted for the $27.15 \%$ and $27.95 \%$ of the total 

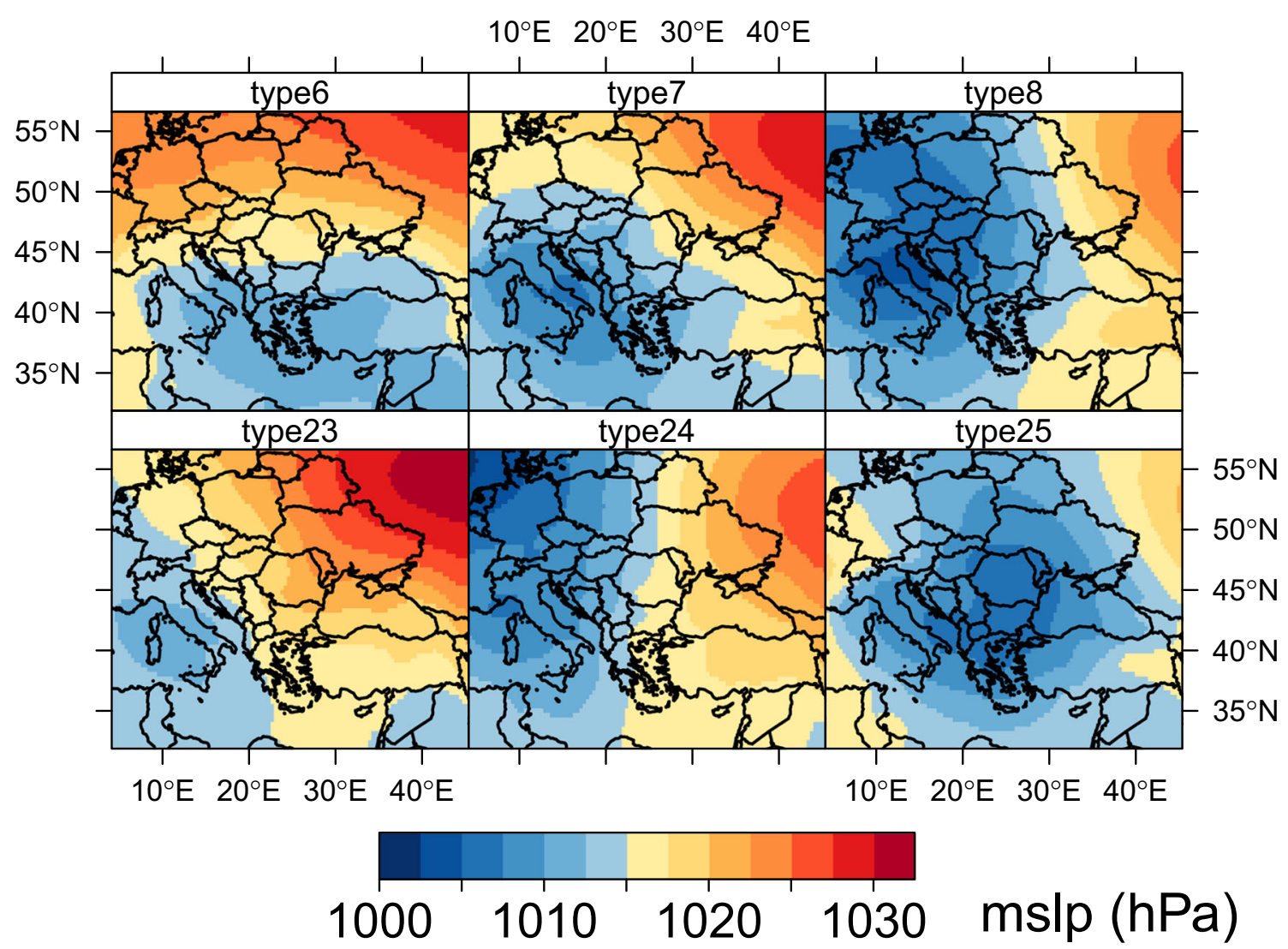

Fig. 5 GWT circulation types resembling to Mediterranean lows upon Balkan peninsula

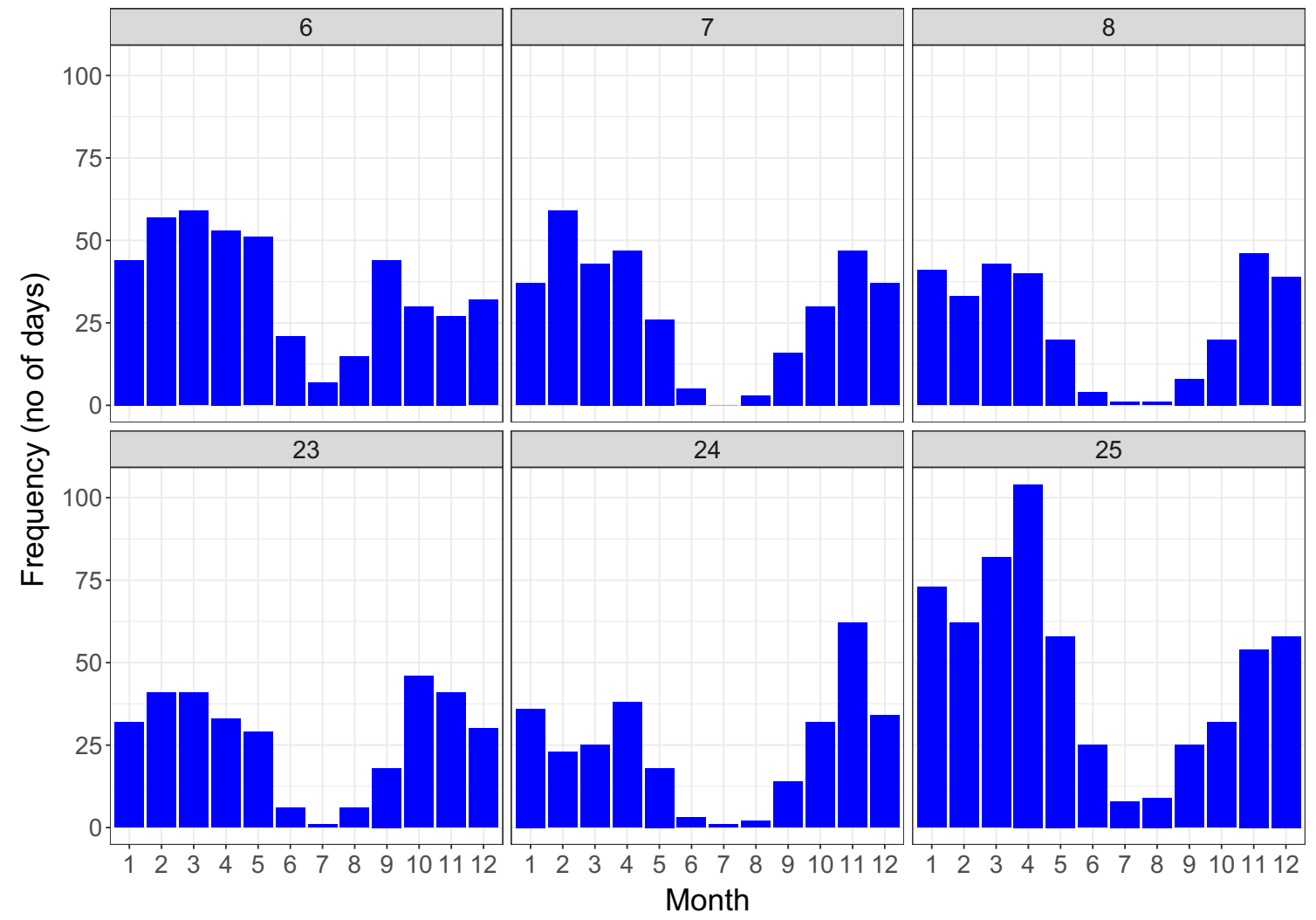

Fig. 6 Monthly frequency of cyclonic weather types in southern Europe 
Fig. 7 Crustal enrichment factors $(\mathrm{EFc})$ for elements measured in rainwater

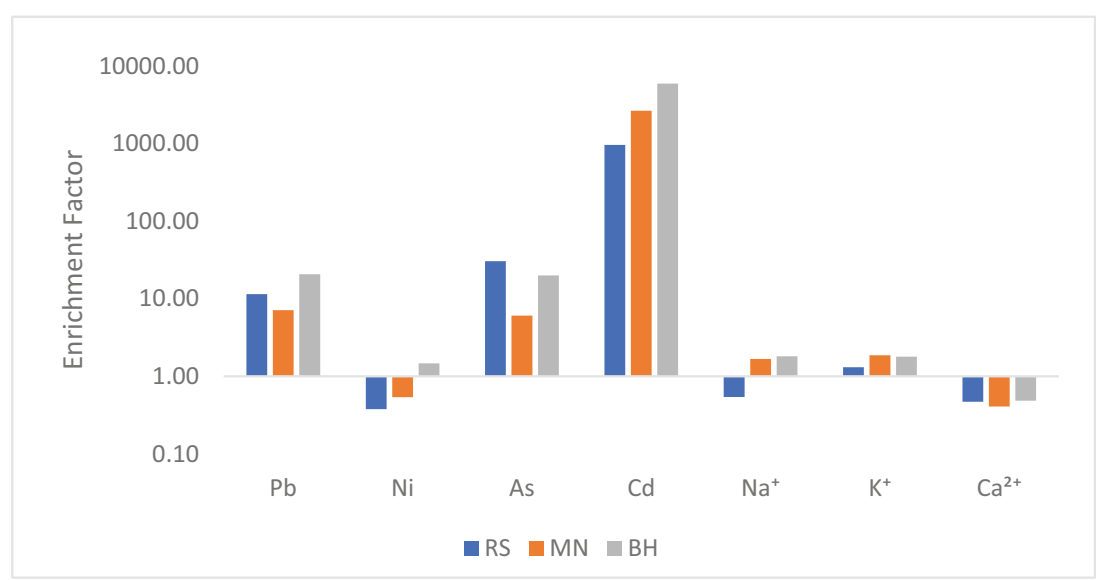

variance, respectively, with high loadings of $\mathrm{Ca}^{2+}, \mathrm{Mg}^{2+}$, and $\mathrm{SO}_{4}{ }^{2-}$, representing mixed/crustal origins.

Primarily, $\mathrm{Ca}^{2+}$ and $\mathrm{Mg}^{2+}$ derive from terrestrial/crustal sources, through the dissolution of dolomites and limestones, but can be attributed to anthropogenic sources too, such as quarries, cement factories (Huang et al. 2008; Niu et al. 2014) and also dust from the un-rehabilitated tailing dams. $\mathrm{SO}_{4}{ }^{2-}$ is also an indicator of anthropogenic sources, and can originate from coal combustion, fuel burnings, and vehicle emissions but in form of post volcanic activity can be attributed to natural sources too. The second factor (F2) can be associated mainly with anthropogenic sources, representing $18.23 \%(\mathrm{MN})$ and $19.28(\mathrm{BH})$ of the total variance, having high loadings of $\mathrm{NO}_{3}{ }^{-}, \mathrm{NH}_{4}{ }^{+}$, and $\mathrm{K}^{+}$. These ions can be derived from fuel combustion, coal burning, traffic emissions, animal/human excrement, and use of fertilizers, respectively (Huang et al. 2008). With $15.97 \%$ at $\mathrm{MN}$ and $16.86 \%$ at $\mathrm{BH}$ of the total variance and higher loadings of sodium and chloride, factor 3 (F3) can be considered to be of marine origin, but as the SSF showed in Table 6, the contribution of marine sources to the rainwater collected at $\mathrm{MN}$ and $\mathrm{BH}$ is not very significant, explaining also the low variance value too. $\mathrm{F} 4$ at $\mathrm{MN}$ explained $13.82 \%$ of the total variance, with high loading of $\mathrm{K}^{+}$, which could be attributed to the use of fertilizers and therefore agricultural sources, but is also considered as a chemical signature of biomass burning (Zunckel et al. 2003; Khare et al. 2004; Zhang et al. 2007). In the case of BH, F4 explained $12.33 \%$ having high loading of ammonium, suggesting the agricultural origin of this ion, indicating use of fertilizers and cattle waste deposits (Keresztesi et al. 2018).

Table 9 summarizes the identified dominated variables in the case of heavy metals, as well as their factor loadings and variances after using varimax rotation technique. From the principal component analysis for heavy metal concentrations, three factors were chosen that explained the $97.23 \%, 96.49 \%$, and $98.27 \%$ of the total variance in the case of RS, MN, and
$\mathrm{BH}$, respectively. PCA in the case of heavy metals was performed in order to determine the specification within the main possible source (anthropogenic). During this analysis, natural determinative factors, as well as regional emissions, were taken under account, in order to define the possible sources. From a geological point of view, the Western and Southern Carpathians have one of the largest coal deposits from EastCentral Europe, respectively, the largest metallogenic area from the Carpathians.

In the case of RS and MN, the first factor presented high loadings of $\mathrm{Cd}$ and $\mathrm{Ni}$, with a variance of $39.28 \%$ and $44.51 \%$, respectively. $\mathrm{Cd}$ and $\mathrm{Ni}$ are emitted by anthropogenic sources, originating from combustion under high temperature (Al-Momani 2003; García et al. 2006; Cheng and You 2010), mainly from factories and power plants which are still using coal as source of energy (Başak and Alagha 2004). Ni can also be released from oil-fired furnaces and ferroalloys (García et al. 2006). The second factor has high loadings of As at RS, as well as at MN, yielding a variance of $32.42 \%$ and $26.33 \%$, respectively. The first factor at $\mathrm{BH}$ accounts for $39.94 \%$ of the total variance and has high loading values for As and $\mathrm{Cd}$. As mainly comes from industrial and anthropogenic sources, but it also has a terrestrial source (Yongming et al. 2006). The most important anthropogenic inputs for As are from smelter operations and fossil fuel combustion (Smedley and Kinniburgh 2000).

At BH, F2 suggests anthropogenic sources and fossil fuel combustion, having $31.89 \%$ of the total variance and a high loading of Ni. The third factor (F3) explained the $25.53 \%, 25.65 \%$, and $26.44 \%$ of the total variance having high loadings of $\mathrm{Pb}$ at $\mathrm{RS}, \mathrm{MN}$, and $\mathrm{BH}$, respectively. $\mathrm{F} 3$ also represents anthropogenic sources, since $\mathrm{Pb}$ mainly comes from combustion processes and traffic emissions, but it also can occur from single sources, like large smelters, since a major emission source for $\mathrm{Cd}$ and $\mathrm{Pb}$ is the primary non-ferrous metal production (Szefer and Szefer 1986; García et al. 2006). 


\section{General air flow transport patterns}

The dominant trajectories and patterns were calculated using 24h back trajectory from January 2014 to December 2017, over a 4year period. In order to decipher the origin of the dominant air parcels first one 24-h back trajectory of every day was calculated, hence a new trajectory was started every day with the same ending height of $2000 \mathrm{~m}$ above ground level (AGL).

This altitude was used, since the air masses coming from south have to cross the Carpathian Mountains. The total number of back trajectories obtained was 4383, 1461 for each location. All of the back trajectories of each location were clustered using SPVAR (cluster spatial variance) calculations and then the total spatial variance (TSV) (Su et al. 2015) was calculated, respectively. SPVAR is the sum of the squared distances between the endpoints of the cluster's component trajectories and the mean of the trajectories in that cluster (Draxler and Hess 1997; Perry and Soule 2012). Finally, the optimum number of clusters was selected using the TSV change as well.

Cluster analysis established 5 trajectory groups for each location in the studied period (January 1, 2014-December 31, 2017) (Fig. 8), which represented the general air flow pathways arriving at $\mathrm{RS}, \mathrm{MN}$, and $\mathrm{BH}$ in terms of direction and wind speed at 2000-m AGL. Predominant transport regimes were similar at all three locations, being classified as $\mathrm{NW}, \mathrm{W}, \mathrm{SW}$, and $\mathrm{S}$ flows and regional recirculation. Analyzing Fig. 8, it can be seen that a smaller percentage of the air masses came from the NW and $\mathrm{W}$ flows, their sum accounting for $41 \%$ at RS, $32 \%$ at MN, and $24 \%$ in the case of $\mathrm{BH}$, respectively. Air flows originating from $\mathrm{S}$ and $\mathrm{SW}$, representing $29 \%$ at $\mathrm{RS}, 35 \%$ at $\mathrm{MN}$, and $31 \%$ at $\mathrm{BH}$, respectively, are also known as Foehn winds. These air masses have a traditional Foehn effect with adiabatic heating and dryadiabatic heating from the ground surface along the fetch of the wind (Takane et al. 2017) causing sudden and dramatic increases in the temperature. One of the major impacts of this wind is desiccation that occurs in the lee of the mountain range or it may have a negative influence on the human health and behavior. The Foehn effect is responsible for the lack of correlation between sea salt ions in the rainwater collected at the studied areas. In approximately $40 \%$ of the cases at all sampling locations, air masses originating from regional recirculation (from Central and Eastern Romania) have eastern tendency, with relative short distance transport.
Fig. 8 Backward trajectory distribution obtained with HYSPLIT for the three locations for the 2014-2017 period

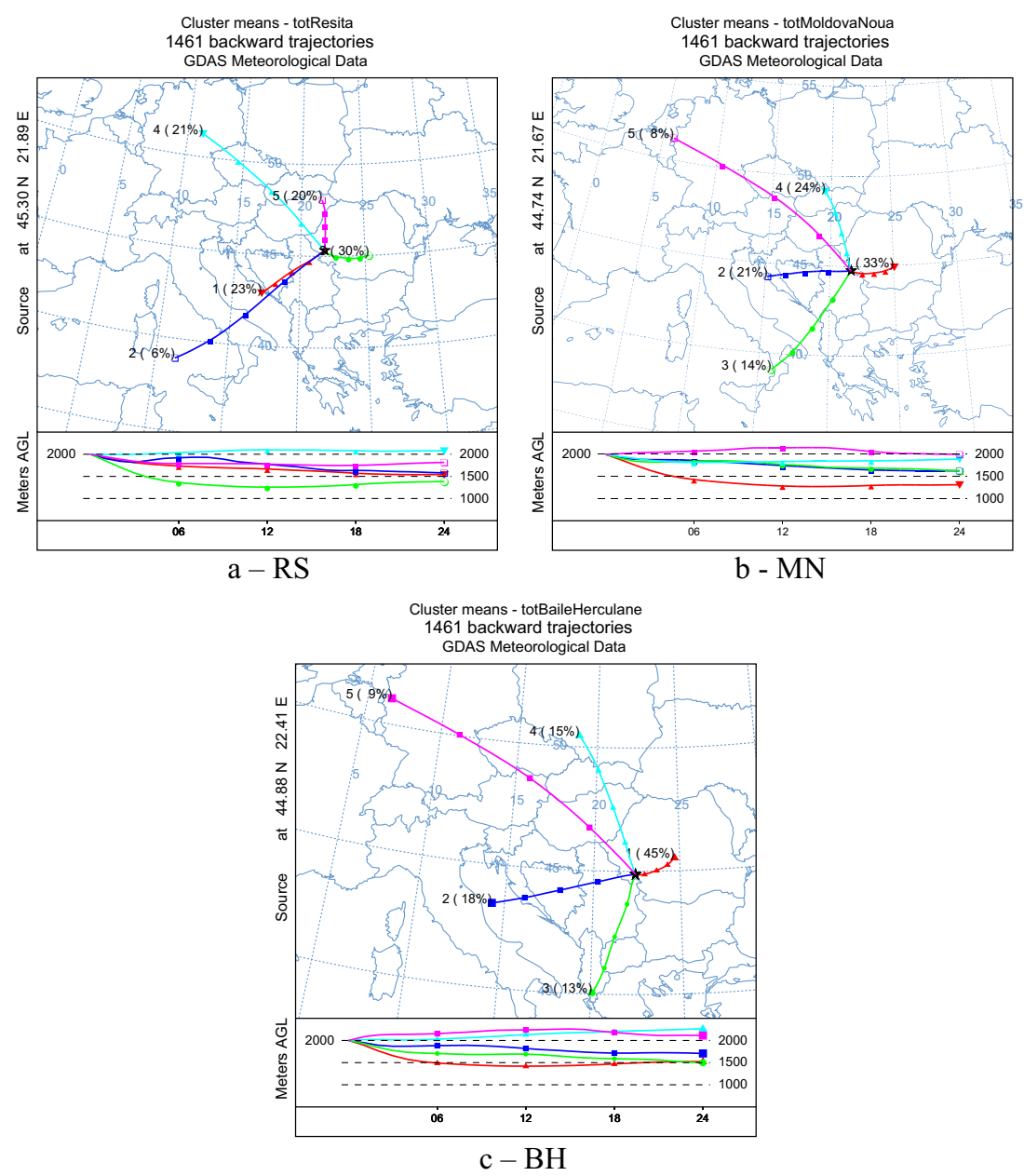


According to the clusters origin and transport pattern, each can be classified taking into consideration their potential atmospheric loads: anthropogenic, partially crustal impacted (clusters 1, 3, 4, and 5 for RS; clusters 1, 2, 4, and 5 for $\mathrm{MN}$; clusters 1, 3, 4, and 5 for $\mathrm{BH}$ ); and anthropogenic, marine, and partially crustal impacted (cluster 2 at RS, 3 at MN and 2 at $\mathrm{BH}$, respectively). This leads to the conclusion that long-range transported aerosols and pollutants $(\sim 60 \%)$ originated from N, NW, and SW, while more than $30 \%$ of the aerosols (natural or anthropogenic) originated from local and nearby activities. Romania's greatest coal mines are situated near the studied areas, while to N-NW from the sampling sites Europe's largest ore mines can be found, with numerous tailings dams and tailings ponds. The influence of these pollutant sources can be seen in the air mass trajectory distribution as well.

\section{Conclusions}

Rainwater composition and sources of major ions and heavy metals were studied during a period of 4 years, considering the characteristic atmospheric circulations, the main air mass transport routes, and the Foehn effect. Atmospheric circulations and distribution of precipitation amount showed the presence of the orographic convection, which affects the sea salt concentration of rainwater through the adiabatic processes that occur on the leeward slopes of the Dinaric Alps. Air masses crossing the Dinaric Alps and Balkan Peninsula lose their content of humidity through the adiabatic compression process, affecting the chemical composition of rainwater. The intensely felt effects of climate change, temperature increase, and the uneven temporal distribution of precipitation amount caused desertification in the studied area. Surface mines, tailings ponds, and dams have a significant influence on the precipitation chemistry. Trajectory cluster analysis showed that air flows originating from S and SW (influenced by Foehn) represent $29 \%$ at $\mathrm{RS}, 35 \%$ at $\mathrm{MN}$, and $31 \%$ at $\mathrm{BH}$ of the total air flow pathways. The $\mathrm{pH}$ values of individual precipitation events varied between 4.33 and 8.43, with an average of 6.70 . Regarding the dominance of major ions and heavy metals in rainwater, $\mathrm{MN}$ and $\mathrm{BH}$ have more resemblance, here $\mathrm{Ca}^{2+}$ and $\mathrm{Mg}^{2+}$ being the most abundant cations, $\mathrm{SO}_{4}{ }^{2-}$ the predominant anion, and $\mathrm{Cd}$ the most dominant heavy metal. In the case of $\mathrm{RS}, \mathrm{Pb}$ has the highest concentration, while regarding anions, the abundance of $\mathrm{Cl}^{-}$can be found, followed by dominant cations like $\mathrm{Ca}^{2+}, \mathrm{NH}_{4}{ }^{+}$, and $\mathrm{Mg}^{2+}$. High concentrations of $\mathrm{Ca}^{2+}$ and $\mathrm{Mg}^{2+}$ are due to the large contribution of soil dust from the un-rehabilitated tailing dams and from the dolomite limestones. At all sampling sites, $\mathrm{Ca}^{2+}$ is the main neutralizing agent, but $\mathrm{Mg}^{2+}$ and $\mathrm{NH}_{4}{ }^{+}$also participated in the neutralization process. WD fluxes for acidic species, such as $\mathrm{SO}_{4}{ }^{2-}$ $(\mathrm{MN}, \mathrm{BH})$ and $\mathrm{Cl}^{-}$(RS), were the highest when the precipitation amounts increased, while in the case of lower precipitation amounts, alkaline species had higher WD rates. In the case of heavy metals, $\mathrm{Cd}$ and $\mathrm{Pb}$ had the highest WD fluxes, with higher concentrations measured after a period when precipitation continued for several days, while during periods with lower rain amount, the wet deposition rate was lower. The overall precipitation contamination with heavy metals at the three sampling sites was assessed by the toxicity potential and degree of contamination, which showed that precipitation at $\mathrm{MN}$ and $\mathrm{BH}$ is considerably contaminated, while at RS a moderate contamination can be observed. The values of toxicity potential suggested an elevated risk for human health in case of rainwater ingestion, especially in rural areas. Spearman correlation and PCA indicated that the chemical characteristic of the rainwater is primarily controlled by sources such as agricultural activities, mixed and crustal sources, traffic, and other anthropogenic, industrial influences, such as mining activities, smelting operations, coal combustion, and metal production. The insignificant marine influence in rainwater can be explained by the Foehn effect, characteristic to the studied region.

Acknowledgements Open access funding provided by Sapientia Hungarian University of Transylvania (EMTE). This work was supported by the Székely Forerunner Fellowship (Forerunner Federation, USA). The authors gratefully acknowledge the NOAA Air Resources Laboratory (ARL) for the provision of the HYSPLIT transport and dispersion model and/or READY website (http://www.ready.noaa.gov) used in this publication. The authors wish to thank the Romanian National Meteorological Administration and the Environmental Protection Agency Caraș-Severin for permission to use rainwater data.

\section{Compliance with ethical standards}

Conflict of interest The authors declare that they have no conflict of interest.

Open Access This article is licensed under a Creative Commons Attribution 4.0 International License, which permits use, sharing, adaptation, distribution and reproduction in any medium or format, as long as you give appropriate credit to the original author(s) and the source, provide a link to the Creative Commons licence, and indicate if changes were made. The images or other third party material in this article are included in the article's Creative Commons licence, unless indicated otherwise in a credit line to the material. If material is not included in the article's Creative Commons licence and your intended use is not permitted by statutory regulation or exceeds the permitted use, you will need to obtain permission directly from the copyright holder. To view a copy of this licence, visit http://creativecommons.org/licenses/by/4.0/.

\section{References}

Adams S, Titus R, Pietersen K et al (2001) Hydrochemical characteristics of aquifers near Sutherland in the Western Karoo, South Africa. J Hydrol 241:91-103. https://doi.org/10.1016/S0022-1694(00) 00370-X 
Al-Momani IF (2003) Trace elements in atmospheric precipitation at Northern Jordan measured by ICP-MS: acidity and possible sources. Atmos Environ 37:4507-4515. https://doi.org/10.1016/S13522310(03)00562-4

Al-Momani IF, Ataman OY, Anwari MA et al (1995a) Chemical composition of precipitation near an industrial area at Izmir, Turkey. Atmos Environ 29:1131-1143. https://doi.org/10.1016/1352-2310(95) 00027-V

Al-Momani IF, Tuncel S, Eler Ü et al (1995b) Major ion composition of wet and dry deposition in the eastern Mediterranean basin. Sci Total Environ 164:75-85. https://doi.org/10.1016/0048-9697(95)04468G

Al-Momani IF, Momani KA, Jaradat QM (2000) Chemical composition of wet precipitation in Irbid, Jordan. J Atmos Chem 35:47-57. https://doi.org/10.1023/A:1006277122888

Anatolaki C, Tsitouridou R (2009) Relationship between acidity and ionic composition of wet precipitation. A two years study at an urban site, Thessaloniki, Greece. Atmos Res 92:100-113. https://doi.org/10. 1016/j.atmosres.2008.09.008

Anil I, Alagha O, Karaca F (2017) Effects of transport patterns on chemical composition of sequential rain samples: trajectory clustering and principal component analysis approach. Air Qual Atmos Health 10: 1193-1206. https://doi.org/10.1007/s11869-017-0504-x

Báez AP, Padilla H, Cervantes J et al (1997) Rainwater chemistry at the eastern flanks of the Sierra Madre Oriental, Veracruz, Mexico. J Geophys Res 102:23329-23336

Báez A, Belmont R, García R et al (2007) Chemical composition of rainwater collected at a southwest site of Mexico City, Mexico. Atmos Res 86:61-75. https://doi.org/10.1016/j.atmosres.2007.03. 005

Balasubramanian R, Victor T, Chun N (2001) Chemical and statistical analysis of precipitation in Singapore. Water Air Soil Pollut 130: 451-456. https://doi.org/10.1023/A:1013801805621

Barbalace K (2015) Periodic table of elements. EnvironmentalChemistry.com. https://doi.org/10.1134/ S1061934807090018

Bașak B, Alagha O (2004) The chemical composition of rainwater over Büyükçekmece Lake, Istanbul. Atmos Res 71:275-288. https://doi. org/10.1016/j.atmosres.2004.07.001

Beck C, Jacobeit J, Jones PD (2007) Frequency and within-type variations of large-scale circulation types and their effects on lowfrequency climate variability in Central Europe since 1780. Int J Climatol. https://doi.org/10.1002/joc.1410

Behera SN, Sharma M, Aneja VP, Balasubramanian R (2013) Ammonia in the atmosphere: a review on emission sources, atmospheric chemistry and deposition on terrestrial bodies. Environ Sci Pollut Res 20: 8092-8131. https://doi.org/10.1007/s11356-013-2051-9

Brisson E, Demuzere M, Kwakernaak B, Van Lipzig NPM (2011) Relations between atmospheric circulation and precipitation in Belgium. Meteorog Atmos Phys 111:27-39. https://doi.org/10. 1007/s00703-010-0103-y

Burlacu IF, Deak G, Raischi MC et al (2017) Greening solutions applicable in the tailing ponds Tăusani and Bosneag from Moldova Nouă. IOP Conf Ser Mater Sci Eng 209:012097. https://doi.org/ 10.1088/1757-899X/209/1/012097

Cao YZ, Wang S, Zhang G et al (2009) Chemical characteristics of wet precipitation at an urban site of Guangzhou, South China. Atmos Res 94:462-469. https://doi.org/10.1016/j.atmosres.2009.07.004

Celle-Jeanton H, Travi Y, Loyle-Pilot MD et al (2009) Rainwater chemistry at a Mediterranean inland station (Avignon, France): local contribution versus long-range supply. Atmos Res 91:118-126. https:// doi.org/10.1016/j.atmosres.2008.06.003

Cheng MC, You CF (2010) Sources of major ions and heavy metals in rainwater associated with typhoon events in southwestern Taiwan. J Geochem Explor 105:106-116. https://doi.org/10.1016/j.gexplo. 2010.04.010
Cheng MC, You CF, Lin FJ et al (2011) Sources of Cu, $\mathrm{Zn}, \mathrm{Cd}$ and $\mathrm{Pb}$ in rainwater at a subtropical islet offshore northern Taiwan. Atmos Environ 45:1919-1928. https://doi.org/10.1016/j.atmosenv.2011. 01.034

Chubaka CE, Whiley H, Edwards JW, Ross KE (2018) A Review of Roof Harvested Rainwater in Australia 2018

Conradie EH, Van Zyl PG, Pienaar JJ et al (2016) The chemical composition and fluxes of atmospheric wet deposition at four sites in South Africa. Atmos Environ 146:113-131. https://doi.org/10.1016/j. atmosenv.2016.07.033

Cornes RC, van der Schrier G, van den Besselaar EJM, Jones PD (2018) An ensemble version of the E-OBS temperature and precipitation data sets. J Geophys Res Atmos. https://doi.org/10.1029/ 2017JD028200

De Souza PA, Zamboni W, Mello D, Maldonado J (2006) Artigo. 29: 471-476

Dee DP, Uppala SM, Simmons AJ et al (2011) The ERA-interim reanalysis: configuration and performance of the data assimilation system. Q J R Meteorol Soc 137:553-597. https://doi.org/10.1002/qj.828

Draxler RR, Hess GD (1997) Description of the HYSPLIT4 modeling system. Techreport 24pp. Tech. Memo. ERL ARL-224

Draxler RR, Rolph GD (2013) HYSPLIT (HYbrid Single-Particle Lagrangian Integrated Trajectory). NOAA Air Resour. Lab, College Park

Esteban P, Jones PD, Martín-Vide J, Mases M (2005) Atmospheric circulation patterns related to heavy snowfall days in Andorra, Pyrenees. Int J Climatol. https://doi.org/10.1002/joc.1103

Facchini Cerqueira MR, Pinto MF, Derossi IN et al (2014) Chemical characteristics of rainwater at a southeastern site of Brazil. Atmos Pollut Res 5:253-261. https://doi.org/10.5094/APR.2014.031

Falarz M (2007) Snow cover variability in Poland in relation to the macro- and mesoscale atmospheric circulation in the twentieth century. Int J Climatol. https://doi.org/10.1002/joc.1505

Fleig AK, Tallaksen LM, James P et al (2015) Attribution of European precipitation and temperature trends to changes in synoptic circulation. Hydrol Earth Syst Sci. https://doi.org/10.5194/hess-19-30932015

Fujita S, Takahashi A, Weng J-H et al (2000) Precipitation chemistry in East Asia. Atmos Environ 34:525-537. https://doi.org/10.1016/ S1352-2310(99)00261-7

Galloway JN, Thornton JD, Norton SA et al (1982) Trace metals in atmospheric deposition: a review and assessment. Atmos Environ 16:1677-1700. https://doi.org/10.1016/0004-6981(82)90262-1

García R, del Torres MC, Padilla H et al (2006) Measurement of chemical elements in rain from rancho Viejo, a rural wooded area in the state of Mexico, Mexico. Atmos Environ 40:6088-6100. https://doi.org/ 10.1016/j.atmosenv.2006.05.048

Gioda A, Mayol-Bracero OL, Scatena FN et al (2013) Chemical constituents in clouds and rainwater in the Puerto Rican rainforest: Potential sources and seasonal drivers. Atmos Environ 68:208220. https://doi.org/10.1016/j.atmosenv.2012.11.017

Granat L (1972) On the relation between $\mathrm{pH}$ and the chemical composition in atmospheric precipitation. Tellus 24:550-560. https://doi.org/ 10.1111/j.2153-3490.1972.tb01581.x

Hakanson L (1980) An ecological risk index for aquatic pollution control.a sedimentological approach. Water Res 14:975-1001. https://doi.org/10.1016/0043-1354(80)90143-8

Haylock MR, Hofstra N, Klein Tank AMG et al (2008) A European daily high-resolution gridded data set of surface temperature and precipitation for 1950-2006. J Geophys Res Atmos. https://doi.org/10. 1029/2008JD010201

Hernández-Crespo C, Martín M (2015) Determination of background levels and pollution assessment for seven metals $(\mathrm{Cd}, \mathrm{Cu}, \mathrm{Ni}, \mathrm{Pb}$, $\mathrm{Zn}, \mathrm{Fe}, \mathrm{Mn}$ ) in sediments of a Mediterranean coastal lagoon. Catena 133:206-214. https://doi.org/10.1016/j.catena.2015.05.013 
Herrera J, Rodríguez S, Baéz AP (2009) Chemical composition of bulk precipitation in the metropolitan area of Costa Rica, Central America. Atmos Res 94:151-160. https://doi.org/10.1016/j. atmosres.2009.05.004

Honório BAD, Horbe AMC, Seyler P (2010) Chemical composition of rainwater in western Amazonia - Brazil. Atmos Res 98:416-425. https://doi.org/10.1016/j.atmosres.2010.08.001

Huang Y, Wang Y, Zhang L (2008) Long-term trend of chemical composition of wet atmospheric precipitation during 1986-2006 at Shenzhen City, China. Atmos Environ 42:3740-3750. https://doi. org/10.1016/j.atmosenv.2007.12.063

Izquierdo R, Avila A, Alarcón M (2012) Trajectory statistical analysis of atmospheric transport patterns and trends in precipitation chemistry of a rural site in NE Spain in 1984-2009. Atmos Environ 61:400 408. https://doi.org/10.1016/j.atmosenv.2012.07.060

Jawad Al Obaidy AHM, Joshi H (2006) Chemical composition of rainwater in a tropical urban area of northern India. Atmos Environ 40: 6886-6891. https://doi.org/10.1016/j.atmosenv.2005.01.031

Kaneyasu N, Yoshikado H, Mizuno T et al (1999) Chemical forms and sources of extremely high nitrate and chloride in winter aerosol pollution in the Kanto Plain of Japan. Atmos Environ 33:17451756. https://doi.org/10.1016/S1352-2310(98)00396-3

Kaya G, Tuncel G (1997) Trace element and major ion composition of wet and dry depositon in Ankara, Turkey. Atmos Environ 31:39853998. https://doi.org/10.1016/S1352-2310(97)00221-5

Keene WC, Pszenny AP, Galloway JN, Hawley ME (1986) Sea-salt corrections and interpretation of constituent ratios in marine precipitation. J Geophys Res 91:6647. https://doi.org/10.1029/ JD091iD06p06647

Keresztesi Á, Petres S, Ghita G et al (2018) Ammonium neutralization effect on rainwater chemistry in the basins of the Eastern Carpathians-Romania. Rev Chim 69:57-63

Keresztesi Á, Birsan M-V, Nita I-A, Bodor Z, Szép R (2019) Assessing the neutralisation, wet deposition and source contributions of the precipitation chemistry over Europe during 2000-2017. Environ Sci Eur 31:50-15. https://doi.org/10.1186/s12302-019-0234-9

Khare P, Goel A, Patel D, Behari J (2004) Chemical characterization of rainwater at a developing urban habitat of northern India. Atmos Res 69:135-145. https://doi.org/10.1016/j.atmosres.2003.10.002

Kulshrestha UC, Sarkar AK, Srivastava SS, Parashar DC (1995) Wetonly and bulk deposition studies at New Delhi (India). Water Air Soil Pollut 85:2137-2142. https://doi.org/10.1007/BF01186150

Kulshrestha UC, Sarkar AK, Srivastava SS, Parashar DC (1996) Investigation into atmospheric deposition through precipitation studies at New Delhi (India). Atmos Environ 30:4149-4154. https://doi.org/10.1016/1352-2310(96)00034-9

Kumar R, Rani A, Singh SP et al (2002) A long term study on chemical composition of rainwater at Dayalbagh, a suburban site of semiarid region. J Atmos Chem 41:265-279. https://doi.org/10.1023/A: 1014955715633

Lara LB, Artaxo P, Martinelli LA et al (2001) Chemical composition of rainwater and anthropogenic influences in the Piracicaba River Basin, Southeast Brazil. Atmos Environ 35:4937-4945

Likens GE, Wright RF, Galloway JN et al (1979) Acid rain. Sci Am 241: 43-51. https://doi.org/10.1038/scientificamerican1079-43

Liu WH, Zhao JZ, Ouyang ZY, Söderlund L, Liu GH (2005) Impacts of sewage irrigation on heavy metal distribution and contamination in Beijing, China. Environ Int 31:805-812. https://doi.org/10.1016/j. envint.2005.05.042

Lü P, Han G, Wu Q (2017) Chemical characteristics of rainwater in karst rural areas, Guizhou Province, Southwest China. Acta Geochim 36: 1-5. https://doi.org/10.1007/s11631-017-0238-3

Luo W, Lu Y, Giesy JP, Wang T, Shi Y, Wang G, Xing Y (2007) Effects of land use on concentrations of metals in surface soils and ecological risk around Guanting Reservoir, China. Environ Geochem Health 29:459-471. https://doi.org/10.1007/s10653-007-9115-z
Mahato K, Singh K, Singh K, Tiwari K (2016) Assessment of major ionic compositions and anthropogenic influences in the rainwater over a coal mining environment of Damodar River basin. India. 2:461474. https://doi.org/10.7508/pj.2016.04.008

Malassa H, Al-Rimawi F, Al-Khatib M, Al-Qutob M (2014) Determination of trace heavy metals in harvested rainwater used for drinking in Hebron (south West Bank, Palestine) by ICP-MS. Environ Monit Assess 186:6985-6992. https://doi.org/10.1007/ s10661-014-3904-5

Migliavacca D, Teixeira EC, Wiegand F et al (2005) Atmospheric precipitation and chemical composition of an urban site, Guaíba hydrographic basin, Brazil. Atmos Environ 39:1829-1844. https://doi.org/ 10.1016/j.atmosenv.2004.12.005

Morais S, e Costa FG, de Lourdes Pereir M (2012) Heavy metals and human health. Environ Heal - Emerg Issues Pract https://doi.org/10. $5772 / 29869$

Niu H, He Y, Lu XX et al (2014) Chemical composition of rainwater in the Yulong Snow Mountain region, Southwestern China. Atmos Res 144:195-206. https://doi.org/10.1016/j.atmosres.2014.03.010

Nollet LML (2007) Handbook of water analysis, 2nd edn. CRC Press, Taylor and Francis Group, Boca Raton

Okay C, Akkoyunlu BO, Tayanç M (2002) Composition of wet deposition in Kaynarca, Turkey. Environ Pollut 118:401-410. https://doi. org/10.1016/S0269-7491(01)00292-5

Perry B, Soule P (2012) Aerosol-precipitation interactions in the southern Appalachian Mountains aerosol-precipitation interactions in the southern Appalachian Mountains. https://doi.org/10.5194/acpd-125487-2012

Philipp A, Beck C, Huth R, Jacobeit J (2016) Development and comparison of circulation type classifications using the COST 733 dataset and software. Int J Climatol 36:2673-2691. https://doi.org/10.1002/ joc. 3920

Plaisance H, Coddeville P, Guillermo R, Roussel I (1996) Spatial variability and source identification of rural precipitation chemistry in France. Sci Total Environ 180:257-270. https://doi.org/10.1016/ 0048-9697(95)04943-6

Poissant L, Schmit JP, Béron P (1994) Trace inorganic elements in rainfall in the Montreal Island. Atmos Environ 28:339-346. https://doi.org/ 10.1016/1352-2310(94)90109-0

Pu W, Quan W, Ma Z, Shi X, Zhao X, Zhang L, Wang Z, Wang W (2017) Long-term trend of chemical composition of atmospheric precipitation at a regional background station in Northern China. Sci Total Environ 580:1340-1350. https://doi.org/10.1016/j.scitotenv.2016. 12.097

Puxbaum H, Haumer G, Moser K, Ellinger R (1993) ^126 Seasonalvariation of $\mathrm{HNO} 3, \mathrm{HCL}, \mathrm{SO} 2, \mathrm{NH} 3$ and particulate matter at a rural site in northeastern.pdf. 27:2445-2447

Rao PSP, Tiwari S, Matwale JL et al (2016) Sources of chemical species in rainwater during monsoon and non-monsoonal periods over two mega cities in India and dominant source region of secondary aerosols. Atmos Environ 146:90-99. https://doi.org/10.1016/j.atmosenv. 2016.06.069

Rao W, Han G, Tan H et al (2017) Chemical and Sr isotopic characteristics of rainwater on the Alxa Desert Plateau, North China: implication for air quality and ion sources. Atmos Res 193:163-172. https:// doi.org/10.1016/j.atmosres.2017.04.007

Rastogi N, Sarin MM (2005) Chemical characteristics of individual rain events from a semi-arid region in India: three-year study. Atmos Environ 39:3313-3323. https://doi.org/10.1016/j.atmosenv.2005. 01.053

Reimann C, Filzmoser P, Garrett RG (2005) Background and threshold: critical comparison of methods of determination. Sci Total Environ 346:1-16. https://doi.org/10.1007/978-3-642-35470-0_54

Riccio A, Giunta G, Chianese E (2007) The application of a trajectory classification procedure to interpret air pollution measurements in 
the urban area of Naples (Southern Italy). Sci Total Environ 376: 198-214. https://doi.org/10.1016/j.scitotenv.2007.01.068

Ruprecht H, Sigg L (1990) Interactions of aerosols ( ammonium sulfate, ammonium nitrate and ammonium chloride ) and of gases ( $\mathrm{Hcl}$, Hno3 ) with fogwater. 24

Salomons W (1995) Environmental impact of metals derived from mining activities: processes, predictions, prevention. $\mathrm{J}$ Geochem Explor 52:5-23. https://doi.org/10.1016/0375-6742(94)00039-E

Samara C, Tsitouridou R (2000) Fine and coarse ionic aerosol components in relation. Water Air Soil Pollut 120:71-88. https://doi.org/ 10.1023/A:1005267021828

Seinfeld JH (1986) Atmospheric chemistry and physics of air pollution

Seinfield J, Pandis S (1998) Atmospheric chemistry and physics. Atmos Chem Phys 6:3181-3210

Singh KP, Singh VK, Malik A, Sharma N, Murthy RC, Kumar R (2007) Hydrochemistry of wet atmospheric precipitation over an urban area in northern Indo-gangetic plains. Environ Monit Assess 131:237254. https://doi.org/10.1007/s10661-006-9472-6

Smedley PL, Kinniburgh DG (2000) Source and behaviour of arsenic in natural waters. Br Geol Surv 61

Stoiber RE, Rose WI (1974) Fumarole incrustations at active central american volcanoes. Geochim Cosmochim Acta 38:495-516. https://doi.org/10.1016/0016-7037(74)90037-4

Su L, Yuan Z, Fung JCH, Lau AKH (2015) A comparison of HYSPLIT backward trajectories generated from two GDAS datasets. Sci Total Environ 506-507:527-537. https://doi.org/10.1016/j.scitotenv. 2014.11.072

Szefer P, Szefer K (1986) (Received January 29th, 1986; accepted February 24th, 1986). 57:79-89

Szép R, Mateescu E, Nechifor AC, Keresztesi Á (2017) Chemical characteristics and source analysis on ionic composition of rainwater collected in the Carpathians "Cold Pole," Ciuc basin, Eastern Carpathians, Romania. Environ Sci Pollut Res 24:27288-27302. https://doi.org/10.1007/s11356-017-0318-2

Takane Y, Kondo H, Kusaka H et al (2017) Foehnlike wind with a traditional foehn effect plus dry-diabatic heating from the ground surface contributing to high temperatures at the end of a leeward area. J Appl Meteorol Climatol 56:2067-2079. https://doi.org/10.1175/JAMCD-16-0257.1

Tiwari S, Srivastava MK, Bisht DS (2008) Chemical composition of rainwater in Panipat, an industrial city in Haryana. Indian J Radio Space Phys 37:443-449

Tiwari S, Chate DM, Bisht DS et al (2012) Rainwater chemistry in the North Western Himalayan Region, India. Atmos Res 104-105:128138. https://doi.org/10.1016/j.atmosres.2011.09.006

Tiwari S, Hopke PK, Thimmaiah D et al (2016) Nature and sources of ionic species in precipitation across the indo-gangetic plains, India.
Aerosol Air Qual Res 16:943-957. https://doi.org/10.4209/aaqr. 2015.06.0423

USEPA (2012) 2012 edition of the drinking water standards and health advisories. 2012 Ed drink water stand heal Advis 2-6. EPA 822-S12-001

Uygur N, Karaca F, Alagha O (2010) Prediction of sources of metal pollution in rainwater in Istanbul, Turkey using factor analysis and long-range transport models. Atmos Res 95:55-64. https://doi.org/ 10.1016/j.atmosres.2009.08.007

Valenta P, Nguyen VD, Nornberg HW (1986) Acid and heavy metal pollution by wet deposition. Sci Total Environ 55:311-320. https:// doi.org/10.1016/0048-9697(86)90188-9

Varmuza K, Filzmoser P (2010) Introduction to multivariate statistical analysis in chemometrics

Wang H, Han G (2011) Chemical composition of rainwater and anthropogenic influences in Chengdu, Southwest China. Atmos Res 99: 190-196. https://doi.org/10.1016/j.atmosres.2010.10.004

Wu Q, Han G, Tao F, Tang Y (2012) Chemical composition of rainwater in a karstic agricultural area, Southwest China: the impact of urbanization. Atmos Res 111:71-78. https://doi.org/10.1016/j.atmosres. 2012.03.002

Wu Y, Xu Z, Liu W et al (2016) Chemical compositions of precipitation at three non-urban sites of Hebei Province, North China: influence of terrestrial sources on ionic composition. Atmos Res 181:115-123. https://doi.org/10.1016/j.atmosres.2016.06.009

Xiao J (2016) Chemical composition and source identification of rainwater constituents at an urban site in Xi???an. Environ Earth Sci 75:112. https://doi.org/10.1007/s12665-015-4997-z

Xu Z, Li Y, Tang Y, Han G (2009) Chemical and strontium isotope characterization of rainwater at an urban site in Loess Plateau, Northwest China. Atmos Res 94:481-490. https://doi.org/10.1016/ j.atmosres.2009.07.005

Yongming H, Peixuan D, Junji C, Posmentier ES (2006) Multivariate analysis of heavy metal contamination in urban dusts of Xi'an, Central China. Sci Total Environ 355:176-186. https://doi.org/10. 1016/j.scitotenv.2005.02.026

Zhang M, Wang S, Wu F et al (2007) Chemical compositions of wet precipitation and anthropogenic influences at a developing urban site in southeastern China. Atmos Res 84:311-322. https://doi.org/ 10.1016/j.atmosres.2006.09.003

Zunckel M, Saizar C, Zarauz J (2003) Rainwater composition in northeast Uruguay. Atmos Environ 37:1601-1611. https://doi.org/10.1016/ S1352-2310(03)00007-4

Publisher's note Springer Nature remains neutral with regard to jurisdictional claims in published maps and institutional affiliations. 